Article

\title{
Synthesis, Anticancer Activity, and Preliminary Pharmacokinetic Evaluation of 4,4-Disubstituted Curcuminoid 2,2-bis(Hydroxymethyl)Propionate Derivatives
}

\author{
Der-Yen Lee ${ }^{1}$, Yu-Chi Hou ${ }^{2}$, Jai-Sing Yang ${ }^{3}$, Hui-Yi Lin ${ }^{4}$, Tsu-Yuan Chang ${ }^{2}$, \\ Kuo-Hsiung Lee ${ }^{5,6} \mathbb{D}$, Sheng-Chu Kuo ${ }^{2,4, *}$ and Min-Tsang Hsieh ${ }^{2,4,6, * \mathbb{C}}$ \\ 1 Graduate Institute of Integrated Medicine, China Medical University, No. 91, Hsueh-Shih Road, \\ Taichung 40402, Taiwan; deryen.lee@mail.cmu.edu.tw \\ 2 School of Pharmacy, China Medical University, Taichung 40402, Taiwan; houyc@mail.cmu.edu.tw (Y.-C.H.); \\ u103003309@cmu.edu.tw (T.-Y.C.) \\ 3 Department of Medical Research, China Medical University Hospital, China Medical University, \\ Taichung 40447, Taiwan; jaisingyang@gmail.com \\ 4 Research Center for Chinese Herbal Medicine, China Medical University, Taichung 404, Taiwan; \\ pingababy@yahoo.com.tw \\ 5 Natural Products Research Laboratories, UNC Eshelman School of Pharmacy, University of North Carolina, \\ Chapel Hill, NC 27599, USA; khlee@unc.edu \\ 6 Chinese Medicinal Research and Development Center, China Medical University Hospital, \\ Taichung 40447, Taiwan \\ * Correspondence: sckuo@mail.cmu.edu.tw (S.-C.K.); t21917@mail.cmu.edu.tw (M.-T.H.); \\ Tel.: +886-4-22030760 (S.-C.K.); +886-4-22053366-5605 (M.-T.H.)
}

Academic Editor: Ping-Chung Kuo

check for updates

Received: 13 January 2020; Accepted: 22 January 2020; Published: 22 January 2020

\begin{abstract}
Compound 1 is a curcumin di-O-2,2-bis(hydroxymethyl)propionate that shows significant in vitro and in vivo inhibitory activity against MDA-MB-231 cells with eight to ten-fold higher potency than curcumin. Here, we modified the $\alpha$-position (C-4 position) of the central 1,3-diketone moiety of 1 with polar or nonpolar functional groups to afford a series of 4,4-disubstituted curcuminoid 2,2-bis(hydroxymethyl)propionate derivatives and evaluated their anticancer activities. A clear structure-activity relationship of compound 1 derivatives focusing on the functional groups at the C-4 position was established based on their anti-proliferative effects against the MDA-MB-231 and HCT-116 cell lines. Compounds 2-6 are 4,4-dimethylated, 4,4-diethylated, 4,4-dibenzylated, 4,4-dipropargylated and 4,4-diallylated compound 1 , respectively. Compounds $2 \mathrm{~m}-6 \mathrm{~m}$, the ester hydrolysis products of compounds 2-6, respectively, were synthesized and assessed for anticancer activity. Among all compound $\mathbf{1}$ derivatives, compound $\mathbf{2}$ emerged as a potential chemotherapeutic agent for colon cancer due to the promising in vivo anti-proliferative activities of $2\left(\mathrm{IC}_{50}=3.10\right.$ $\pm 0.29 \mu \mathrm{M})$ and its ester hydrolysis product $2 \mathrm{~m}\left(\mathrm{IC}_{50}=2.17 \pm 0.16 \mu \mathrm{M}\right)$ against HCT-116. The preliminary pharmacokinetic evaluation of 2 implied that 2 and $2 \mathrm{~m}$ are main contributors to the in vivo efficacy. Compound 2 was further evaluated in an animal study using HCT-116 colon tumor xenograft bearing nude mice. The results revealed a dose-dependent efficacy that led to tumor volume reductions of $27 \%, 45 \%$, and $60 \%$ at 50,100 , and $150 \mathrm{mg} / \mathrm{kg}$ doses, respectively. The established structure-activity relationship and pharmacokinetic outcomes of $\mathbf{2}$ is the guidance for future development of 4,4-disubstituted curcuminoid 2,2-bis(hydroxymethyl)- propionate derivatives as anticancer drug candidates.
\end{abstract}

Keywords: curcuminoid derivatives; prodrug; colon cancer; breast cancer; active metabolites 


\section{Introduction}

Curcumin [(1E,6E)-1,7-bis(4-hydroxy-3-methoxyphenyl)hepta-1,6-diene-3,5-dione, the structure of which is shown in Scheme 1], the naturally occurring phytochemical from the rhizome of Curcuma longa L., is a polyphenol with a symmetrical structure composed of two ortho-methoxyphenol rings connected to each other through a flexible conjugated hydrocarbon chain. It is a versatile therapeutic agent against cancer [1] and exhibits diverse pharmacological effects, including antidiabetic [2], antiviral [3], analgesic [4], nephroprotective [5], and cardioprotective effects [6], via regulating the gene expression [7] and protein binding [8]. Similar to some phenolic natural products, curcumin is a multi-target anticancer agent [9] with the ability to interfere with several signaling pathways associated with tumor progression, metastasis, apoptosis, and angiogenesis [10].

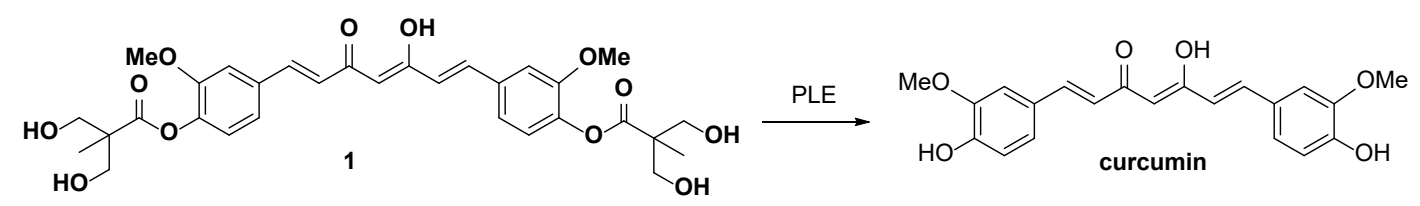

Scheme 1. PLE mediated hydrolysis of 1.

While curcumin shows promising therapeutic properties, its low solubility and poor chemical and metabolic stability hinder further drug development [11]. The low chemical stability of curcumin is demonstrated by its rapid decomposition upon exposure to light or high temperatures $\left(>70{ }^{\circ} \mathrm{C}\right)[12]$. The compound decomposes into several degradation products, including a bicyclopentadione derivative, vanillin, feruloylmethane, and ferulic acid. The degradation of curcumin presumably results from its autoxidation [13], wherein the starting radical species is formed through hydrogen atom removal from the phenolic moiety. The phenolic group with an easily abstractable proton and the keto-enol system display significant hydrogen-donating abilities [14] that could initiate the autoxidative degradation of curcumin. The poor metabolic stability of curcumin can be ascribed to the presence of two phenolic hydroxyl groups that are prone to the formation of glucuronide and sulfate conjugates through the phase II metabolic process [15]. Moreover, the enone moiety of curcumin is accessible to nicotinamide adenine dinucleotide phosphate (NADHP) cytochrome P450 reductase or alcohol dehydrogenases, allowing curcumin to be readily reduced to the hydrogenated metabolites dihydrocurcumin, tetrahydrocurcumin, hexahydrocurcumin, and hexahydrocurcuminol [16].

Medicinal chemists have performed structural optimizations of curcumin to improve its stability and activity. Most of these attempts were focused on modifying the phenolic hydroxyl groups, keto-enol system, and enone moiety of curcumin [17-20]. However, the first two abovementioned structural features are required for radical scavenging activity, which is regarded as vital for curcumin chemopreventive and anti-inflammatory activities [21]. In addition, the enone moiety of curcumin, serving as the electrophilic Michael acceptor, can interact with cysteine or selenocysteine residues in proteins to mediate biological activities [22]. Thus, finding a balance between structural stability and biological potency can become challenging. According to the FDA [23], about 30\% of the curcumin clinical trials stalled at stage II, mostly due to discrepancies between in vitro activity and in vivo response. Accordingly, to achieve success in clinical trials, obtaining a more definite picture of signaling pathways and ADME profiling for curcumin is recommended.

We previously developed a series of curcuminoid prodrugs by modifying the phenolic hydroxyl groups of curcumin into a 2,2-bis(hydroxymethyl)propionate group [24]. Among the derivatives, the curcumin 2,2-bis(hydroxymethyl)propionate 1 exhibited stability and solubility superior to those of curcumin. Particularly, 1 showed comparable anticancer activity against MDA-MB-231 cells in vitro and in vivo and had 8 to 10 times more potency than curcumin. Subsequently, the $\alpha$-position in the central 1,3-diketone moiety (C-4 position) of 1 were alkylated with methyl, ethyl, benzyl, and propargyl groups to give compounds 2, 3, 4, and 5, respectively. Among them, 2, 3, and 5 showed more potent 
in vitro anti-proliferative activity than 1 against HCT-116 cells; therefore, were recommended them as potential therapeutic agents for colon cancer [24]. In our recent in vitro studies on the enzymatic hydrolysis of $\mathbf{1}$, we demonstrated that treating 1 with porcine liver esterase (PLE) cleaves its two ester groups gradually to form curcumin (see supporting information). Compounds 2-5 are ester-based derivatives and structurally correlated to 1 . Therefore, we predicted that a high concentration of esterase, as particularly found in the intestinal tract and mucosa [25], would hydrolyze 2, 3, 4, and 5 into their metabolites $\mathbf{2 m}, \mathbf{3 m}, \mathbf{4 m}$, and $5 \mathrm{~m}$, respectively (Scheme 2). However, the anticancer activity of $\mathbf{2 m - 5 m}$ should be evaluated prior to the further in vivo investigations. Compounds $\mathbf{2}-\mathbf{5}$ were substituted with two nonpolar alkyl chains at the C-4 position with the loss of keto-enol tautomerism. The anticancer activity of compound 1 derivatives, which were substituted with two hydrophilic units or two polar side chains at the C-4 position, still remains unclear.

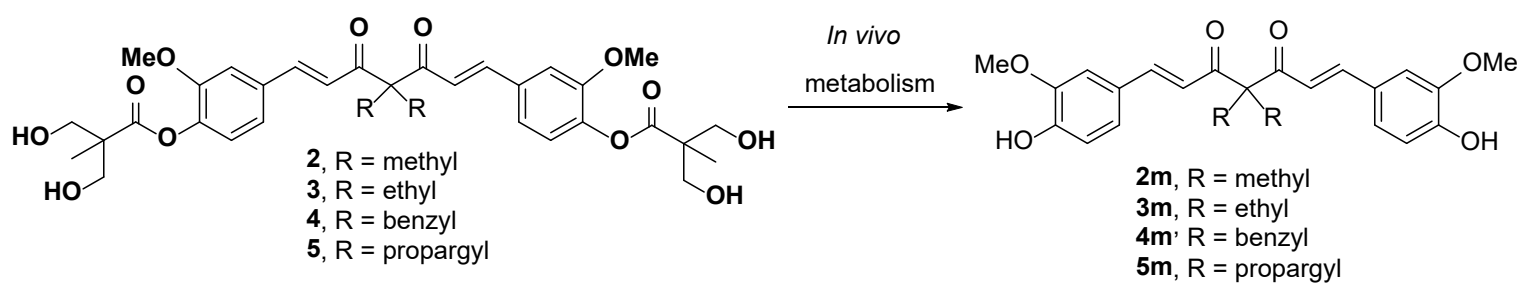

Scheme 2. In vivo enzymatic hydrolysis of $\mathbf{2}-\mathbf{5}$.

Herein, we report the successful replacement of the acidic $\alpha$-hydrogens at the C-4 position of compound 1 with polar or nonpolar functional groups to produce compounds 6, 9, 10, 11, 12, and 14. Compounds $\mathbf{2 m - 6 m}$ were prepared through the chemical hydrolysis of corresponding parent compounds 2-6. The anticancer activities of 2-6,9-12, 14 and 2m-6m were evaluated in vitro. A selected compound was submitted for preliminary pharmacokinetic study and antitumor study. The detailed descriptions of the synthetic design, in vitro screening, and in vivo study of the abovementioned compounds are presented as follows.

\section{Results and Discussion}

\subsection{Chemistry}

The detailed synthesis of compound 1 derivatives (substituted at the C-4 position with allyl (6), hydroxymethyl (10), acetoxymethyl (11), methoxymethyl (12)), novel 2,6-dimethyl curcumin (DMC) derivatives (13 and 15), and the ester hydrolysis products of derivatives showing potential anticancer activity $(\mathbf{2 m}, \mathbf{3 m}, \mathbf{4 m}, \mathbf{5 m}, \mathbf{6 m}, \mathbf{1 6}$, and 17) are depicted in Schemes 3 and 4 . As shown in Scheme 3, compound $\mathbf{6}$ was synthesized according to a procedure established for the synthesis of 2-5. Compound 7, prepared by the esterification of curcumin with 2,2,5-trimethyl-1,3-dioxane-5-carboxylic acid, was treated with 1,8-diazabicyclo[5.4.0]undec-7-ene (DBU) and formaldehyde in THF to produce intermediary compound 8. The latter was used without column chromatographic purification in acid-promoted hydrolysis at room temperature to produce 9 with an overall yield of $6 \%$ for two synthetic steps.

Compound 9, however, proved unstable, slowly decomposing even when kept at $4{ }^{\circ} \mathrm{C}$ and presenting an NMR spectrum comprising a messy jungle of peaks after being dissolved in DMSO- $\mathrm{d}_{6}$ for 1 week at room temperature. The low stability of 9 may have been due to self- or cross-hydrolysis, such that the two hydroxyl groups at the C-4 alkyl chains cleaved the ester linkage of the 2,2-bis(hydroxymethyl)propionate group. Previously, we had found that upon exposure to alcohol for several hours, the ester linkages of $\mathbf{1}$ were broken under neutral or basic conditions, leading to the conversion of $\mathbf{1}$ to curcumin and several unknown products. Therefore, we modified the hydroxymethyl group of $\mathbf{9}$ and were able to produce compounds $\mathbf{1 0}$ and 11. To prepare 10, compound 9 was acetylated with acetyl chloride in the presence of $\mathrm{Et}_{3} \mathrm{~N}$, and the resulting di-acetylation intermediate 
was hydrolyzed by hydrochloric acid. Compound 11 was obtained with an overall yield of $5 \%$ following a similar three-step reaction modified for methylation. The stability of these two products at room temperature may have been due to the conversion of the labile hydroxyl groups of the C-4 alkyl chains of $\mathbf{1 0}$ and $\mathbf{1 1}$ into non-nucleophilic methyl and acetyl groups, respectively, which prevented degradation.

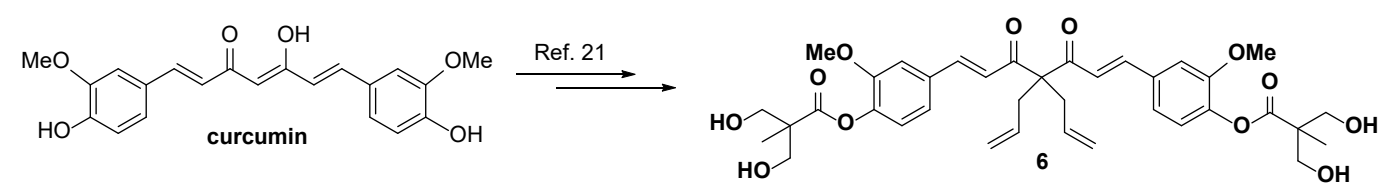

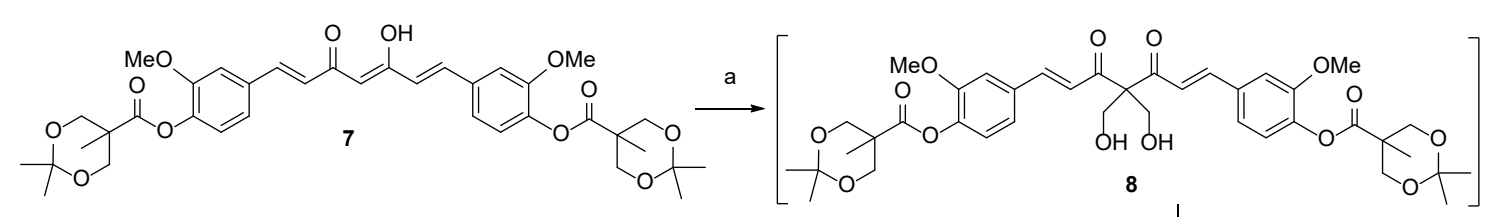<smiles>COc1cc(/C=C/C(=O)C(CO)(CO)C(=O)/C=C/c2ccc(OC(=O)C(CO)(CO)CO)c(OC)c2)ccc1OC(=O)C(CO)(CO)CO</smiles><smiles>COc1cc(/C=C/C(=O)C(CO)(C(=O)/C=C/c2ccc(OC(=O)C(CO)(CO)CO)c(OC)c2)C(=O)OC(C)=O)ccc1OC(=O)C(CO)(CO)CO</smiles><smiles>COc1ccc(/C=C/C=C(O)/C=C/C(=O)/C=C/c2ccc(OC)c(OC)c2)cc1OC</smiles><smiles>CCC(CO)(CO)C(=O)OCC(COC(=O)C(CO)(CO)CO)(C(=O)C=Cc1ccc(OC)c(OC)c1)C(=O)C=Cc1ccc(OC)c(OC)c1</smiles><smiles>COCC1(C(=O)Cl)COC(C)(C)OC1</smiles>

Scheme 3. Reagents and Conditions: (a) Formaldehyde in THF, DBU, $0^{\circ} \mathrm{C}$ to rt, $2 \mathrm{~h}$; (b) $\mathrm{HCl}, \mathrm{MeOH}, \mathrm{rt}$, $1 \mathrm{~h}, 6 \%$ for two steps; (c) $\mathrm{Et}_{3} \mathrm{~N}$, acetyl chloride, DCM, rt, $12 \mathrm{~h}$; then $\mathrm{HCl}, \mathrm{MeOH}, \mathrm{rt}, 1 \mathrm{~h}, 3 \%$ for three steps; (d) $\mathrm{K}_{2} \mathrm{CO}_{3}, \mathrm{CH}_{3} \mathrm{I}, \mathrm{DMF}, \mathrm{rt}, 6 \mathrm{~h}$; then $\mathrm{HCl}, \mathrm{MeOH}, \mathrm{rt}, 1 \mathrm{~h}, 4 \%$ for three steps; (e) Formaldehyde in THF, DBU, $0{ }^{\circ} \mathrm{C}$ to rt, $2 \mathrm{~h}, 42 \%$; (f) Compound 13, $\mathrm{Et}_{3} \mathrm{~N}, \mathrm{DCM}, \mathrm{rt}, 12 \mathrm{~h}$; and (g) HCl, MeOH, $1 \mathrm{~h}, 7 \%$ for two steps.

Because DMC is a dimethylated derivative of curcumin [26] that exhibits better anticancer activity and stability than curcumin, we synthesized a novel DMC derivative (compound 12) in which C-4 was substituted with two bulky 2,2-bis(hydroxymethyl)propionate groups. To produce this derivative, commercially available DMC was reacted with DBU and formaldehyde in THF. The reaction of 12 with 2,2,5-trimethyl-1,3-dioxane-5-carbonyl chloride 13 [27] in the presence of $\mathrm{Et}_{3} \mathrm{~N}$ provided a diol intermediate, which was then hydrolyzed by hydrochloric acid in $\mathrm{MeOH}$ to yield compound 14. In addition, as illustrated in Scheme 4 , compounds $\mathbf{2} \mathbf{m}-\mathbf{6} \mathbf{m}$ were prepared through the NaOMe-mediated hydrolysis of their corresponding parent compounds $\mathbf{2}-\mathbf{6}$, with high yield. 


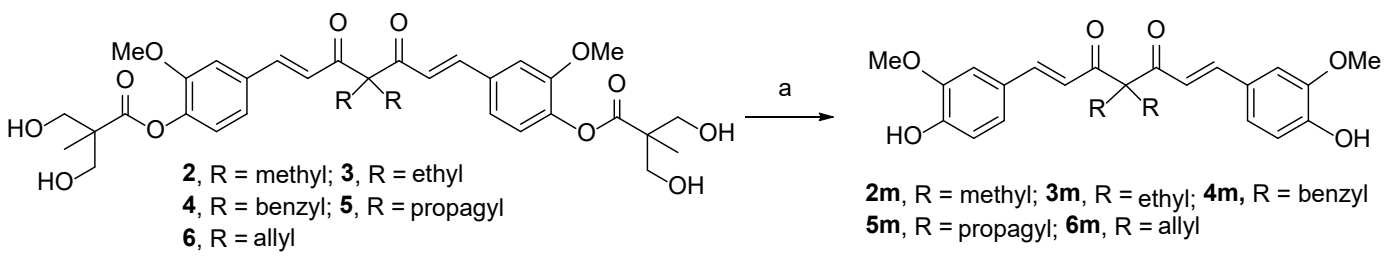

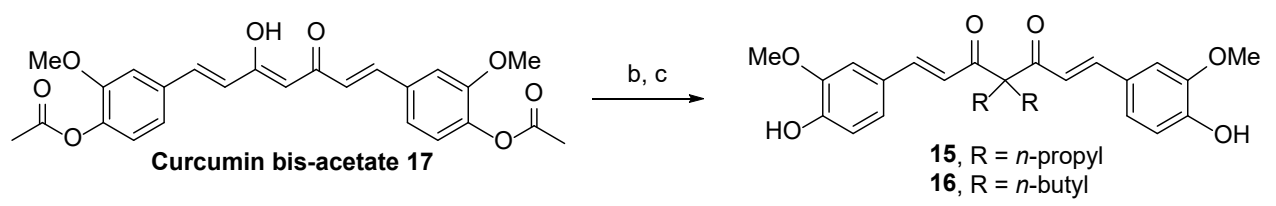

Scheme 4. Reagents and Conditions: (a) NaOMe, $\mathrm{MeOH}, \mathrm{rt}, 2 \mathrm{~h}, 82-87 \%$; (b) $\mathrm{K}_{2} \mathrm{CO}_{3}$, alkyl iodide, DMF, rt, 20 h; and (c) NaOMe, MeOH, rt, 3 h, 28-33\% for two steps.

For SAR analysis, compounds 15 and 16, which were substituted with two straight alkyl chains with three or four carbons at the C4 position, were prepared from curcumin bisacetate 17 [28] via a two-step procedure comprising $\mathrm{K}_{2} \mathrm{CO}_{3}$-induced dialkylation and $\mathrm{NaOMe-mediated} \mathrm{hydrolysis.}$ For the synthesis of four possible phase I metabolites of compound $\mathbf{2}$, compound $\mathbf{2} \mathbf{m}$ was subjected to hydrogenation reactions. As shown in Scheme 5, compound 18 is a partially hydrogenated product that can be prepared in $19 \%$ yield by treating compound $2 \mathrm{~m}$ with $\mathrm{H}_{2(\mathrm{~g})}(1.0 \mathrm{~atm}$, balloon) and a catalytic amount of $10 \% w / w \mathrm{Pd} / \mathrm{C}$ in ethyl acetate. When the solvent was changed from ethyl acetate to methanol, the hydrogenation reaction yielded the fully hydrogenated diketone 19 in $52 \%$ yield and $\beta$-hydroxy ketone 20 in $23 \%$ yield. Finally, the reduction of 20 with $\mathrm{NaBH}_{4}$ in $\mathrm{MeOH}$ at room temperature (rt) for $2 \mathrm{~h}$ provided the desired diol compound 21 in $31 \%$ yield.

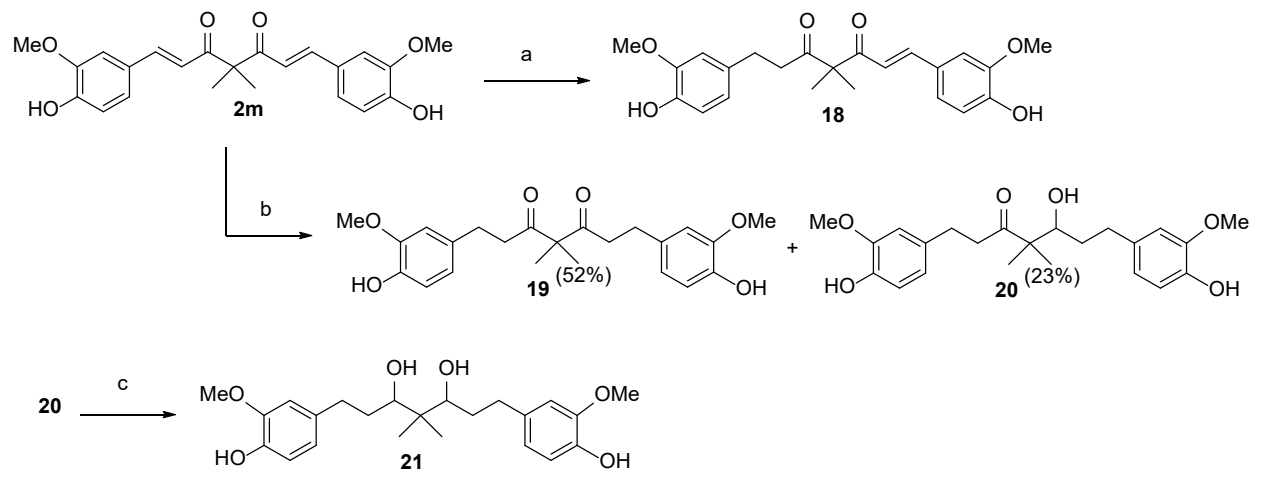

Scheme 5. Reagents and Conditions: (a) $10 \%$ w/w Pd/C, ethyl acetate, $\mathrm{rt}, 1 \mathrm{~h}, 19 \%$; (b) $10 \% \mathrm{w} / \mathrm{w} \mathrm{Pd} / \mathrm{C}$, $\mathrm{MeOH}, \mathrm{rt}, 2 \mathrm{~h}$; and (c) $\mathrm{NaBH}_{4}, \mathrm{MeOH}, 0{ }^{\circ} \mathrm{C}$ to rt, $2 \mathrm{~h}, 31 \%$.

\subsection{Structure-Activity Relationship}

As mentioned above, we synthesized $\mathbf{2}-\mathbf{5}$ and evaluated their anti-proliferative activity against the MDA-MB-231 and HCT-116 cell lines (72-h treatment). These compounds, along with all newly synthesized compounds, were screened for anti-proliferative activity against the same TNBC and colon cancer cell lines. The results of the in vitro assay are compiled in Table 1. 
Table 1. The anti-proliferative effects of curcumin derivatives against MDA-MB-231 and HCT-116 cell lines.

\begin{tabular}{|c|c|c|c|c|}
\hline \multirow{2}{*}{ Compound } & \multirow{2}{*}{$\mathbf{R}^{1}$} & \multirow{2}{*}{$\mathbf{R}^{2}$} & \multicolumn{2}{|c|}{$\mathrm{IC}_{50} \mathrm{a}(\mathrm{M}) / 48 \mathrm{~h}$} \\
\hline & & & MDA-MB-231 & HCT-116 \\
\hline Curcumin & $\mathrm{OH}$ & $\mathrm{H}$ & $22.05 \pm 2.97$ & $26.33 \pm 1.38$ \\
\hline 1 & $-\mathrm{O}-\mathrm{O}-\left[\begin{array}{l}\mathrm{OH} \\
-\mathrm{CH} \\
-\mathrm{OH}\end{array}\right.$ & $\mathrm{H}$ & $3.06 \pm 0.18$ & $6.25 \pm 0.60$ \\
\hline 2 & $-\mathrm{O}-\mathrm{H}-\stackrel{\mathrm{C}}{-} \underset{[\mathrm{OH}}{-\mathrm{OH}}$ & methyl & $2.25 \pm 0.10$ & $3.10 \pm 0.29$ \\
\hline 3 & 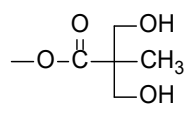 & ethyl & $3.02 \pm 0.15$ & $1.93 \pm 0.01$ \\
\hline 4 & $-\mathrm{O}-\mathrm{O}-\left[\begin{array}{l}\mathrm{OH} \\
-\mathrm{CH} \\
-\mathrm{OH}\end{array}\right.$ & benzyl & $2.45 \pm 0.24$ & $7.66 \pm 0.61$ \\
\hline 5 & $-\mathrm{O}-\stackrel{\mathrm{C}}{\mathrm{C}}-\left[\begin{array}{l}\mathrm{OH} \\
-{ }_{\mathrm{OH}}\end{array}\right.$ & propargyl & $5.87 \pm 0.10$ & $5.81 \pm 0.23$ \\
\hline 6 & $-\mathrm{O}-\stackrel{\mathrm{O}}{\mathrm{C}}-\frac{\mathrm{OH}}{-} \underset{\mathrm{OH}}{\mathrm{CH}}$ & allyl & $3.13 \pm 0.54$ & $0.92 \pm 0.06$ \\
\hline 9 & $-\mathrm{O}-\mathrm{O}-\left[\begin{array}{l}\mathrm{OH} \\
-\mathrm{OH} \\
-\mathrm{CH}_{3}\end{array}\right.$ & $\mathrm{CH}_{2} \mathrm{OH}$ & $>100$ & $>100$ \\
\hline 10 & $-\mathrm{O}-\mathrm{H}-\underset{-\mathrm{CH}}{-}-{ }_{-\mathrm{OH}}^{\mathrm{OH}}$ & $\mathrm{CH}_{2} \mathrm{OAc}$ & $6.55 \pm 0.04$ & $6.53 \pm 0.01$ \\
\hline 11 & $-\mathrm{O}-\mathrm{H}-\underset{\mathrm{CH}}{-}-{ }_{\mathrm{OH}}^{\mathrm{OH}}$ & $\mathrm{CH}_{2} \mathrm{OMe}$ & $84.92 \pm 1.67$ & $69.08 \pm 3.11$ \\
\hline 12 & $\mathrm{OCH}_{3}$ & $\mathrm{CH}_{2} \mathrm{OH}$ & $53.50 \pm 3.45$ & $58.00 \pm 0.60$ \\
\hline 14 & $\mathrm{OCH}_{3}$ & $\xi \mathrm{H}^{\mathrm{H}_{2}}-\mathrm{O}-\mathrm{C}^{\mathrm{O}}-{ }^{\mathrm{OH}}$ & $57.43 \pm 2.06$ & $40.10 \pm 1.61$ \\
\hline $2 \mathrm{~m}$ & $\mathrm{OH}$ & methyl & $4.17 \pm 0.15$ & $2.17 \pm 0.16$ \\
\hline $3 m$ & $\mathrm{OH}$ & ethyl & $9.12 \pm 0.40$ & $8.18 \pm 0.57$ \\
\hline $4 \mathrm{~m}$ & $\mathrm{OH}$ & benzyl & $36.52 \pm 1.66$ & $9.40 \pm 0.02$ \\
\hline $5 \mathrm{~m}$ & $\mathrm{OH}$ & propargyl & $3.10 \pm 0.15$ & $1.38 \pm 0.06$ \\
\hline $6 \mathrm{~m}$ & $\mathrm{OH}$ & allyl & $6.88 \pm 0.36$ & $4.40 \pm 0.53$ \\
\hline 15 & $\mathrm{OH}$ & propyl & $18.17 \pm 0.53$ & $10.73 \pm 1.63$ \\
\hline 16 & $\mathrm{OH}$ & butyl & $>100$ & $67.00 \pm 3.18$ \\
\hline
\end{tabular}

${ }^{a}$ All data presented are means from at least three experiments with standard deviations of the value quoted.

The anticancer effects of 2-5 against both cell lines were still better or at least similar to that of 1 , although the drug treatment duration was reduced to $48 \mathrm{~h}$. The newly synthesized compound 6 had a higher anti-proliferative activity against HCT-116. Compound 9 was less potent against the cell lines than curcumin and 1, which was used as a reference compound in the current study. We hypothesize that the two polar and hydrophilic side chains at the C-4 position in 9 are the cause for the weak anticancer effects observed for this compound. Another possibility is that 9 decomposed during the screening due to its low stability. Compound 10, having two acetoxymethyl groups rather than hydroxymethyl groups at the C-4 side chains, showed significant improvement in in vitro anticancer 
activities compared to 9; however, it was still less potent than 1. Compound 11, substituted with two methoxymethyl groups at the C-4 position, displayed poor anticancer activity with high $\mathrm{IC}_{50}$ values for both cell lines used.

After listing the compounds in descending order based on their potency against HCT-116 $(6>3>2$ $>5>1>10>4>>11>>9$ ), we concluded that higher polarity and hydrophilicity of the C-4 side chain are detrimental to the anticancer activity of compound 1 derivatives. Alternatively, the DMC derivative 4,4-dihydroxymethyl dimethoxycurcumin (compound 12) displayed low anti-proliferative activity. When the two hydroxyl moieties of 12 both esterified with 2,2-bis(hydroxymethyl)propionic acid, the resulting compound 14 exhibited activities comparable to those of 12, which correlates with our previous findings regarding the unfavorable effect of having a hydrophilic moiety at the C-4 position.

Subsequently, the activities of the ester hydrolysis products $\mathbf{2 m - 6 m}$ were explored. Unexpectedly, $5 \mathrm{~m}$ displayed substantial improvement in anticancer activity by two- to four-fold relative to that of parent 5 . Compound $2 \mathrm{~m}$ exhibited activity similar to that of 2 , whereas $3 \mathrm{~m}, 4 \mathrm{~m}$, and $6 \mathrm{~m}$ showed inferior activity than their corresponding parent compounds 3, 4, and 6. Further screening of $\mathbf{1 5}$ and $\mathbf{1 6}$ revealed an obvious SAR, such that the anticancer activity of these hydrolysis compounds decreased with the increasing length of the C-4 alkyl side chains. In addition, lower structural volume was seemingly preferred to sterically congested side chains, as demonstrated by the analysis of $2 \mathrm{~m}, 3 \mathrm{~m}, \mathbf{1 5}$, $4 \mathrm{~m}$, and 16.

Among all examined compounds, $\mathbf{2}$ and its ester hydrolysis product $\mathbf{2 m}$ possessed significant anticancer activity against MDA-MB-231 and HCT-116; therefore, 2 was chosen for further studies. Notably, the solubility of $\mathbf{2}$ was more significant than that of curcumin as was evident from the vehicle of $\mathbf{2}$ for the following in vivo study. The maximum solubility of $\mathbf{2}$ in the aqueous vehicle comprising $5 \%$ ethanol, $10 \%$ Tween 80 , and $85 \%$ saline was approximately $200 \mathrm{mg} / \mathrm{mL}$, while curcumin was almost insoluble in the vehicle. Based on the logic for the metabolism of curcumin [29] and an ester-type prodrug [30], we speculated that the in vivo metabolism of $\mathbf{2}$ would readily produce $2 \mathbf{m}$. Subsequently, the latter would be converted into glucuronide 22 and sulfate 23 through the phase II metabolism conjugation of hydrogenated products 18, 19, 20, and 21 via the phase I metabolic pathway (Scheme 6). To verify our assumptions, the preliminary pharmacokinetic evaluation of $\mathbf{2}$ was executed.

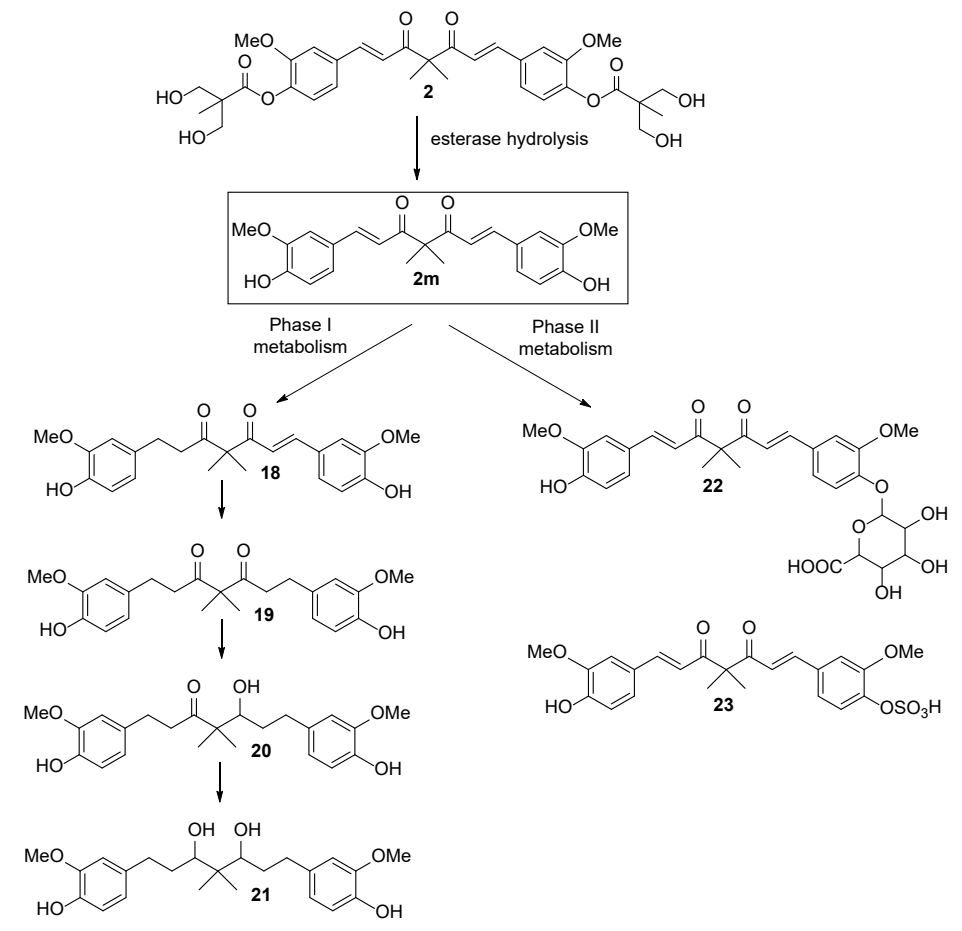

Scheme 6. In vivo metabolism of 2. 


\subsection{The Preliminary Pharmacokinetic Evaluation of 2}

The preliminary in vivo pharmacokinetic evaluation of 2 was designed to identify the anticipated metabolites and evaluate the plasma stability of 2 and $\mathbf{2 m}$. The four possible phase I metabolites 18, 19, 20, and 21 were synthesized and subjected to anti-proliferative screening against MDA-MB-231 and HCT-116. Compound 18 exhibited moderate to weak anti-proliferative activity (MDA-MB-231, $\mathrm{IC}_{50}=$ $\left.36.48 \pm 0.34 \mu \mathrm{M} ; \mathrm{HCT}-116, \mathrm{IC}_{50}=9.64 \pm 0.21 \mu \mathrm{M}\right)$ and the others are inactive against both cell lines $\left(\mathrm{IC}_{50} \geq 100 \mu \mathrm{M}\right)$. The assessment of 2 and relevant metabolites was performed in male Sprague-Dawley rats after the oral administration of 2 at a dose of $100 \mathrm{mg} / \mathrm{kg}$. The LC signals of 2, 2m, and 18-21 was recognized unequivocally by comparison to the signals of standard compounds. The direct analysis of 22 and 23 was not easily attainable due to the low extraction efficiency and high probability of sample loss in LC column. It has been well-documented that curcumin glucuronide and curcumin sulfate can be transformed back into curcumin by the enzyme-mediated hydrolysis reaction [31]. Accordingly, the treatment of $\mathbf{2 2}$ and $\mathbf{2 3}$ with enzyme that contains sulfatase and glucuronidase is supposed to produce $\mathbf{2 m}$. In the current study, the amounts of $\mathbf{2 2}$ and $\mathbf{2 3}$ were not calculated individually but counted as a summary value based on the disparities between the LC signal of $\mathbf{2 m}$ in enzyme-treated and -untreated serum samples.

In practice, LC-MS analysis of one serum sample which was collected at 20 min post-dosing demonstrated the existence of 2, 2m, 18, 19, 20, 21, 22 and 23 (Figure S1 in the Supporting Information). Shown in Figure 1 are the LC signal count-time profiles for 2, 2m, 18, 19, and the comparison of 2m, 22, and 23, following oral administration. The analysis of $\mathbf{2 0}$ and $\mathbf{2 1}$ is not illustrated due to their low LC signal response and non-significant anticancer activity. The maximum blood content of 2 was achieved at $20 \mathrm{~min}$, while the second and third highest appeared at $120 \mathrm{~min}$ and $360 \mathrm{~min}$, respectively, following administration. The multiple peaks of 2 observed in the profile could be attributed to an enterohepatic circulation cycle.

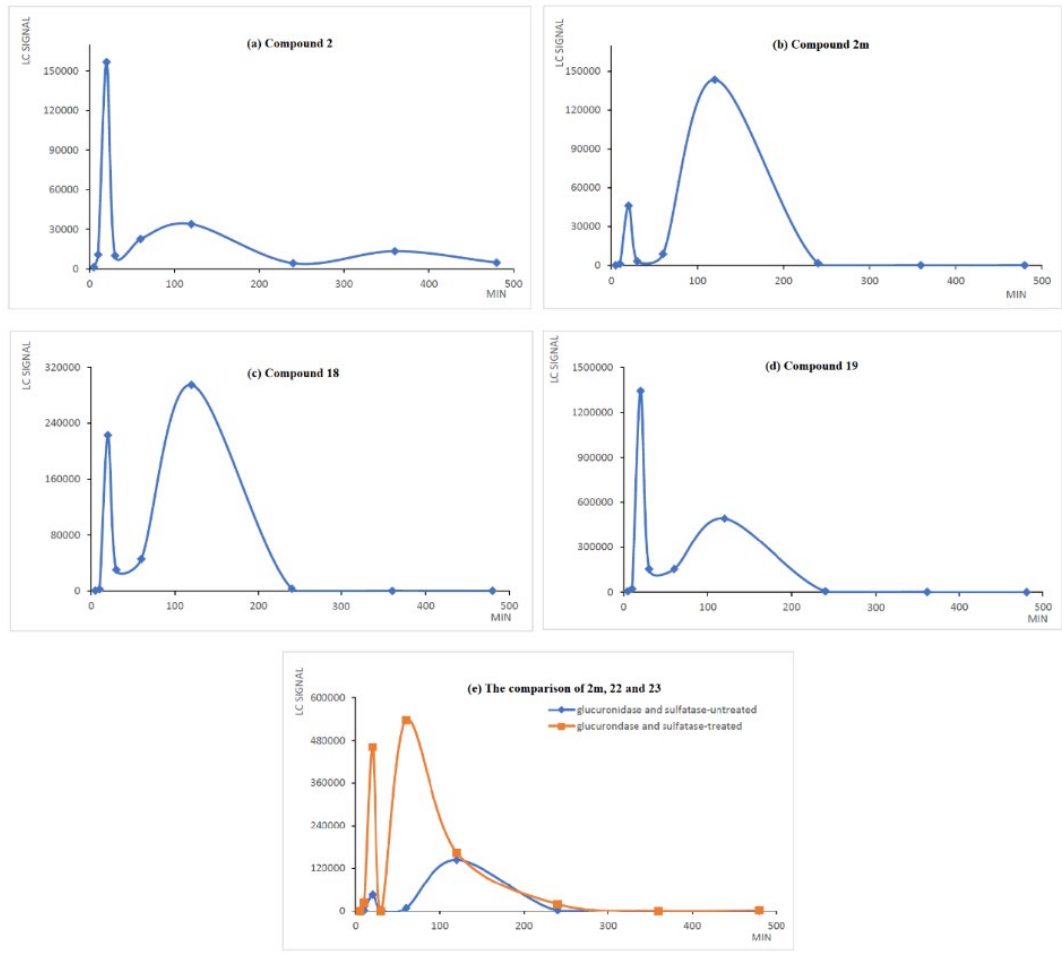

Figure 1. The amount of $2,2 \mathrm{~m}, \mathbf{1 8}, \mathbf{1 9}, \mathbf{2 2}$, and 23 in serum at different time points following a single oral administration of 2 at a dose of $100 \mathrm{mg} / \mathrm{kg}$. The blood samples were collected at 5, 10, 20, 30, 60, $120,240,360$, and $480 \mathrm{~min}$ after the administration of $\mathbf{2}$. The samples were deproteinated and analyzed by HPLC. 
Such behavior, extensively studied in the phenolic drugs, was beneficial in maintaining the circulating concentration of free-form curcumin [32] and may extend the pharmacological effect of drug [33]. The hydrolysis metabolite $\mathbf{2 m}$ emerged from $10 \mathrm{~min}$ and reached its maximum blood content at $120 \mathrm{~min}$, indicating that a medium-to-high esterase-mediated biotransformation proceeded in vivo to yield the efficient absorption of $\mathbf{2 m}$. Subsequently, the phase II metabolic process of $2 \mathrm{~m}$ progressed quickly to produce $\mathbf{2 2}$ and $\mathbf{2 3}$. The ratio of $\mathbf{2} \mathbf{m}$ to its phase II metabolites (22 and $\mathbf{2 3}$ ) is about 1:4 based on the area under the curves in part (e) of Figure 1.

The LC signal count-time profiles of $\mathbf{1 8}$ and $\mathbf{1 9}$ are analogous to that of $\mathbf{2 m}$, implying that phase I reduction reaction also occurred rapidly. Compared to non-formulated curcumin with a short elimination period of $28 \mathrm{~min}$ in the rat model [34], 2 exhibited superior plasma stability. Otherwise, the active metabolite $\mathbf{2} \mathbf{m}$ is equally potent as $\mathbf{2}$ with regard to anticancer activity, and the maximum blood content of $\mathbf{2} \mathbf{m}$ appeared after that of $\mathbf{2}$ could be considered as an extension of drug efficacy of $\mathbf{2}$. Thus, the pharmacokinetic outcome was to guide the following in vivo efficacy study of 2 .

\subsection{In Vivo Antitumor Efficacy of 2}

The therapeutic effect of 2 was evaluated on HCT-116 colon tumor xenograft bearing nude mice. The oral administration of 2 at doses of 50,100 , or $150 \mathrm{mg} / \mathrm{kg}$ bw per day were performed after tumors reached approximately $100 \mathrm{~mm}^{3}$ and continued for 30 consecutive days. 5-Fluorouracil treatment (30 mg/kg bw, i.p., QOD) was used as a positive control. The group treated with compound 2 (100 $\mathrm{mg} / \mathrm{kg}$ ) had a statistically significant reduction in tumor volumes, with a $45 \%$ tumor inhibition ratio observed when compared with the cancerous control mice. Positive control group exhibited a capability to cause $40 \%$ tumor-growth inhibition. There was a clear dose- and time-dependent inhibitory effect on tumor size in the other two groups, in which at 50 and $150 \mathrm{mg} / \mathrm{kg}$ doses the volume of the HCT-116 colon tumor was reduced to $73 \%$ and $40 \%$ of the control, respectively (Figure 2). The body weight of the mice was recorded prior to dosing every $3 \mathrm{~d}$, and the average body weight of each group is depicted in Figure 3. Otherwise, they were monitored for visible signs of toxicity and behavioral changes $1 \mathrm{~h}$ after each administration. No obvious adverse effects were observed between the 2-administrated and control groups.

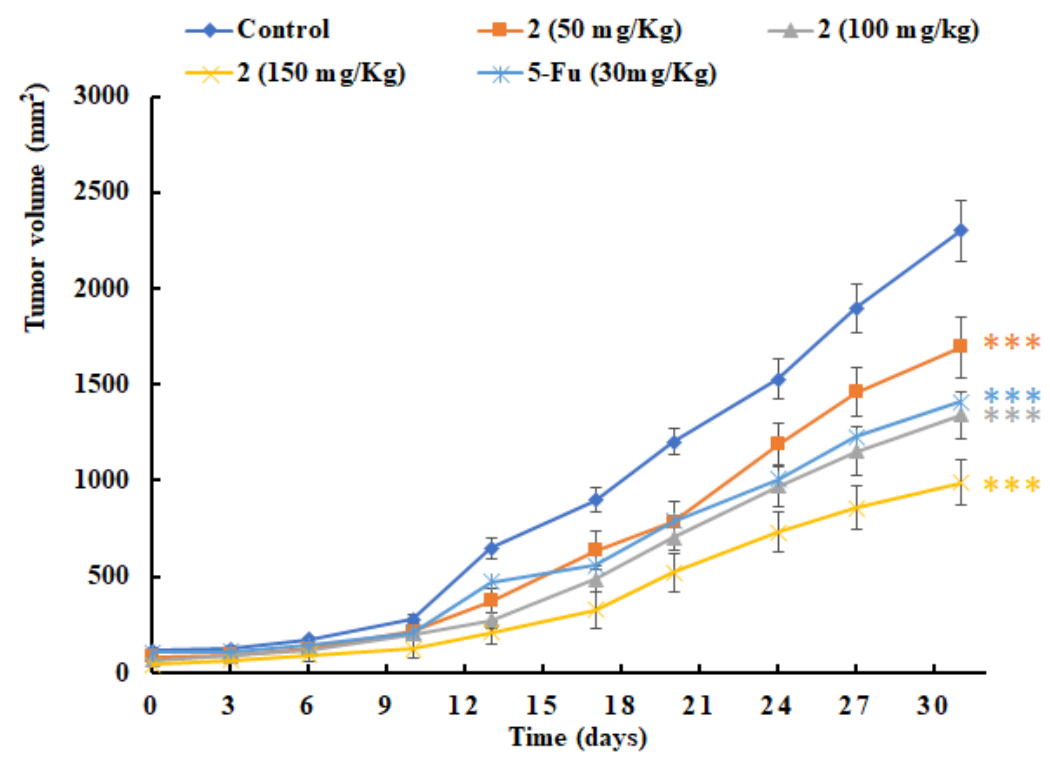

Figure 2. The efficacy study of $\mathbf{2}$. In vivo antitumor activity of compound $\mathbf{2}$ was evaluated in HCT-116 tumor xenograft bearing nude mice. Compound $2(50,100$, or $150 \mathrm{mg} / \mathrm{kg}$, p.o.) was administered once daily and 5-Fluorouracil was administrated ( $30 \mathrm{mg} / \mathrm{kg}$, i.p.) every other day. The results are the mean \pm SEM of six mice in each group. ${ }^{* * *} P<0.001$ compared to untreated control. 


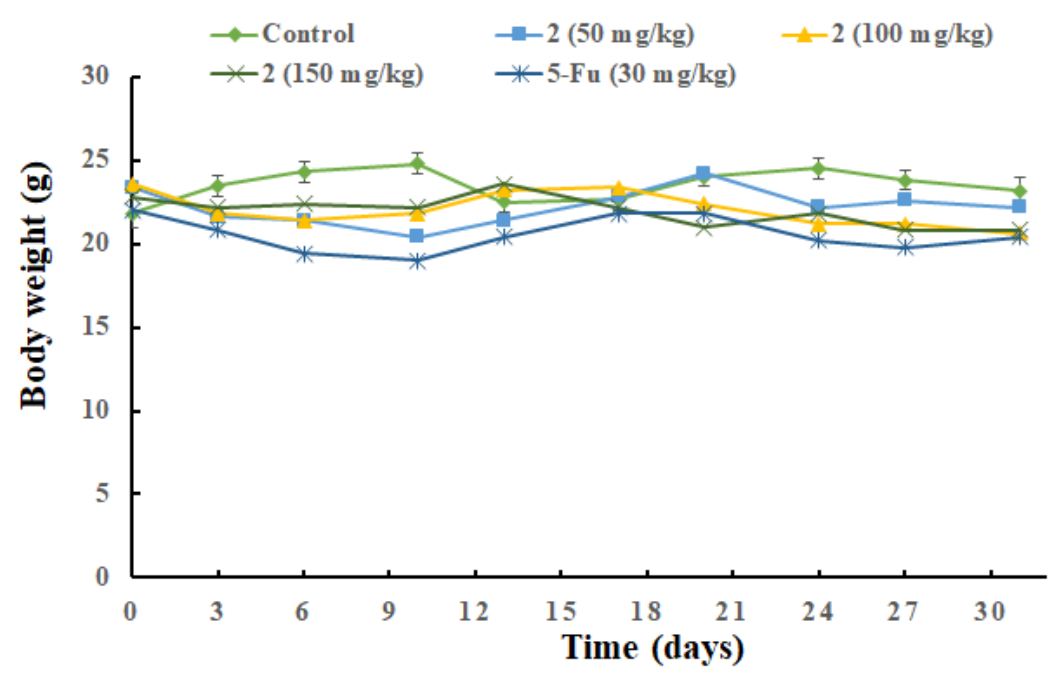

Figure 3. Mean body weight-time profile of 2- administrated and control groups.

\section{Materials and Methods}

\subsection{General Information}

The reactions were performed under an air atmosphere unless otherwise stated. All solvents and reagents were employed as received. Analytical thin layer chromatography (TLC) was performed on $\mathrm{SiO}_{2} 60 \mathrm{~F}_{254}$ plates and flash column chromatography was carried out using $\mathrm{SiO}_{2} 60$ (particle size 0.040-0.055 mm, 230-400 mesh), both of which are available from E. Merck (Darmstadt, Germany). Visualization was performed under UV irradiation at $254 \mathrm{~nm}$ followed by staining with aqueous potassium permanganate $\left[\mathrm{KMnO}_{4}(3 \mathrm{~g})\right.$ and $\mathrm{K}_{2} \mathrm{CO}_{3}(20 \mathrm{~g})$ in $300 \mathrm{~mL}$ of $\mathrm{H}_{2} \mathrm{O}$ containing $5 \mathrm{~mL}$ of an aqueous solution of $\mathrm{NaOH}(5 \%, w / v)]$ and charring by heat gun. ${ }^{1} \mathrm{H}$ - and ${ }^{13} \mathrm{C}-\mathrm{NMR}$ spectra were recorded on a 500 FT NMR instrument (Bruker, Billerica, MA, USA). Chloroform- $d$ and methanol- $d$ were used as solvents and TMS $(\delta=0.00 \mathrm{ppm})$ as an internal standard. Chemical shifts are reported as $\delta$ values in ppm as referenced to TMS. Multiplicities are recorded as s (singlet), $\mathrm{d}$ (doublet), $\mathrm{t}$ (triplet), $q$ (quartet), quint (quintet), sext (sextet), sept (septet), dd (doublet of doublets), dt (doublet of triplets), br (broad), $\mathrm{m}$ (multiplet). Coupling constants $(J)$ are expressed in Hz. LRMS and HRMS were measured by a JMS-HX110 spectrometer (JEOL, Tokyo, Japan) and spectroscopic data were recorded as $m / z$ values. Melting points were measured using an Electrothermal instrument (Anatec Yanaco Inc., Kyoto, Japan).

3.1.1. [(1E,6E)-4,4-Diallyl-3,5-dioxohepta-1,6-diene-1,7-diyl]bis(2-methoxy-4,1-phenylene) bis[3-hydroxy-2-(hydroxymethyl)-2-methylpropanoate] (6)

$\mathrm{Mp}=195-197{ }^{\circ} \mathrm{C} ;{ }^{1} \mathrm{H}-\mathrm{NMR}\left(\mathrm{DMSO}^{\mathrm{d}}{ }_{6}\right) \delta 7.59(\mathrm{~d}, J=15.5 \mathrm{~Hz}, 2 \mathrm{H}), 7.48(\mathrm{~s}, 2 \mathrm{H}), 7.35(\mathrm{dd}, J=8.2$, $1.5 \mathrm{~Hz}, 2 \mathrm{H}), 7.12-7.04(\mathrm{~m}, 4 \mathrm{H}), 5.59-5.52(\mathrm{~m}, 2 \mathrm{H}), 5.12-5.04(\mathrm{~m}, 4 \mathrm{H}), 4.82-4.80(\mathrm{~m}, 4 \mathrm{H}), 3.78(\mathrm{~s}, 6 \mathrm{H}), 3.60$ $(\mathrm{s}, 8 \mathrm{H}), 2.84(\mathrm{~d}, J=7.2 \mathrm{~Hz}, 4 \mathrm{H}), 1.17(\mathrm{~s}, 6 \mathrm{H}) ;{ }^{13} \mathrm{C}$ NMR $\left(\mathrm{DMSO}^{-} \mathrm{d}_{6}\right) \delta 196.8,173.3,151.7,143.1,142.1$, 133.3, 133.2, 123,9, 122.9, 122.8, 119.5, 113.4, 67.4, 64.0, 56.7, 51.0, 35.0, 17.3; HRMS [ESI] ${ }^{+}$calculated for $\mathrm{C}_{37} \mathrm{H}_{45} \mathrm{O}_{12}: 681.2911[\mathrm{M}+\mathrm{H}]^{+}$; found: 681.2903 .

\subsection{2. [(1E,6E)-4,4-bis(Hydroxymethyl)-3,5-dioxohepta-1,6-diene-1,7-diyl]bis(2-methoxy-4,1-phenylene)} bis(2,2,5-trimethyl-1,3-dioxane-5-carboxylate) (8)

To a stirred solution of $7(1.00 \mathrm{~g}, 1.47 \mathrm{mmol})$ in THF $(7.3 \mathrm{~mL}$, containing $0.6 \mathrm{M}$ formaldehyde) was added DBU $(38.9 \mathrm{mg}, 0.04 \mathrm{mmol})$ at $0{ }^{\circ} \mathrm{C}$. The reaction mixture was stirred at the same temperature for $30 \mathrm{~min}$ and then warm to room temperature. After $2 \mathrm{~h}$, the solution was concentrated under vacuum to provide crude compound, which was identified by LRMS [ESI] ${ }^{+}$calculated for $\mathrm{C}_{39} \mathrm{H}_{49} \mathrm{O}_{14}: 741.31$ $[\mathrm{M}+\mathrm{H}]^{+}$; found: 741.33 and used for next step without purification. 
3.1.3. [(1E,6E)-4,4-bis(Hydroxymethyl)-3,5-dioxohepta-1,6-diene-1,7-diyl]bis(2-methoxy-4,1-phenylene) bis[3-hydroxy-2-(hydroxymethyl)-2-methylpropanoate] (9)

A solution of crude $8(0.34 \mathrm{~g})$ and $6 \mathrm{~N} \mathrm{HCl}(0.15 \mathrm{~mL})$ in $\mathrm{MeOH}(1.83 \mathrm{~mL})$ was stirred at room temperature for $1 \mathrm{~h}$. The reaction mixture was concentrated under vacuum to give the crude product, which was purified by flash chromatography on silica gel with $\mathrm{MeOH} / \mathrm{CH}_{2} \mathrm{Cl}_{2}$ (1:20) to afford compound $9(40 \mathrm{mg})$ as an orange oil. Yield $6 \%$ for two steps. ${ }^{1} \mathrm{H}-\mathrm{NMR}\left(\mathrm{DMSO}-\mathrm{d}_{6}\right) \delta 7.52(\mathrm{~d}, J=15.6 \mathrm{~Hz}, 2 \mathrm{H}), 7.44$ $(\mathrm{s}, 2 \mathrm{H}), 7.30(\mathrm{~d}, J=8.2 \mathrm{~Hz}, 2 \mathrm{H}), 7.08-7.04(\mathrm{~m}, 4 \mathrm{H}), 5.16(\mathrm{br} \mathrm{s}, 6 \mathrm{H}), 4.19(\mathrm{~s}, 4 \mathrm{H}), 3.78(\mathrm{~s}, 6 \mathrm{H}), 3.61(\mathrm{~s}, 8 \mathrm{H})$, $1.17(\mathrm{~s}, 6 \mathrm{H})$; LRMS [ESI] ${ }^{+}$calculated for $\mathrm{C}_{33} \mathrm{H}_{40} \mathrm{O}_{14}: 661.25[\mathrm{M}+\mathrm{H}]^{+}$; found: 661.4 .

3.1.4. [(1E,6E)-4,4-bis(Acetoxymethyl)-3,5-dioxohepta-1,6-diene-1,7-diyl]bis(2-methoxy-4,1-phenylene) bis[3-hydroxy-2-(hydroxymethyl)-2-methylpropanoate] (10)

To a stirred solution of crude $8(0.450 \mathrm{~g})$ in DCM $(10 \mathrm{~mL})$ were added $\mathrm{NEt}_{3}(1.0 \mathrm{~mL})$ and acetyl chloride $(0.140 \mathrm{~g}, 1.81 \mathrm{mmol})$ at $0{ }^{\circ} \mathrm{C}$. The reaction mixture was warmed to room temperature and stirred for $12 \mathrm{~h}$. Then $\mathrm{H}_{2} \mathrm{O}(10 \mathrm{~mL})$ and diluted $\mathrm{HCl}_{(\mathrm{aq})}(1 \mathrm{~N}, 3 \mathrm{~mL})$ were added to quench the reaction. The aqueous layer was separated and extracted with $\mathrm{CH}_{2} \mathrm{Cl}_{2}(3 \times 8 \mathrm{~mL})$. The combined organic extracts were washed with brine, dried over $\mathrm{MgSO}_{4}$, filtered and concentrated to give the crude product, which was then treated with $\mathrm{HCl}_{(\mathrm{aq})}(6 \mathrm{~N}, 0.2 \mathrm{~mL})$ in $\mathrm{MeOH}(2 \mathrm{~mL})$ at room temperature. The reaction mixture was stirred at room temperature for $1 \mathrm{~h}$ and then concentrated under vacuum to give the crude product, which was purified on silica gel with $\mathrm{MeOH} / \mathrm{CH}_{2} \mathrm{Cl}_{2}$ (1:20) to afford 10 (33 $\mathrm{mg}$ ) as a yellow solid $\left(\mathrm{mp}=194-196{ }^{\circ} \mathrm{C}\right)$. Yield 3\% for three steps; ${ }^{1} \mathrm{H}-\mathrm{NMR}\left(\mathrm{DMSO}-\mathrm{d}_{6}\right) \delta 7.68(\mathrm{~d}, J=15.5 \mathrm{~Hz}, 2 \mathrm{H}), 7.51$ $(\mathrm{s}, 2 \mathrm{H}), 7.37(\mathrm{~d}, J=8.0 \mathrm{~Hz}, 2 \mathrm{H}), 7.20(\mathrm{~d}, J=15.5 \mathrm{~Hz}, 2 \mathrm{H}), 7.08(\mathrm{~d}, J=8.5 \mathrm{~Hz}, 2 \mathrm{H}), 4.85(\mathrm{t}, J=5.0 \mathrm{~Hz}, 8 \mathrm{H})$, 3.80 (s, $6 \mathrm{H}), 3.65-3.59$ (m, 8H), 1.97 (s, 6H), 1.19 (s, 6H); ${ }^{13}$ C-NMR (DMSO-d 6 ) $\delta 193.1,173.3,170.5,151.7$, 144.6, 142.5, 132.9, 123.9, 122,7, 121.7, 113.6, 64.0, 61.9, 56.7, 51.0, 20.9, 17.3; HRMS [ESI] ${ }^{+}$calculated for $\mathrm{C}_{37} \mathrm{H}_{44} \mathrm{NaO}_{16}: 767.2527[\mathrm{M}+\mathrm{Na}]^{+}$; found: 767.2521.

3.1.5. [(1E,6E)-4,4-bis(Methoxymethyl)-3,5-dioxohepta-1,6-diene-1,7-diyl]bis(2-methoxy-4,1-phenylene) bis[3-hydroxy-2-(hydroxymethyl)-2-methylpropanoate] (11)

To a stirred solution of crude $8(0.453 \mathrm{~g})$ in DMF $(1.0 \mathrm{~mL})$ were added $\mathrm{K}_{2} \mathrm{CO}_{3}(0.240 \mathrm{~g}, 1.73 \mathrm{mmol})$ and $\mathrm{MeI}(0.247 \mathrm{~g}, 1.73 \mathrm{mmol})$ at $0^{\circ} \mathrm{C}$. The reaction mixture was warmed to room temperature and stirred for $6 \mathrm{~h}$. Then $\mathrm{H}_{2} \mathrm{O}(10 \mathrm{~mL})$ and diluted $\mathrm{HCl}_{(\mathrm{aq})}(1 \mathrm{~N}, 3 \mathrm{~mL})$ were added to quench the reaction. The aqueous layer was separated and extracted with EtOAc $(3 \times 8 \mathrm{~mL})$. The combined organic extracts were washed with brine, dried over $\mathrm{MgSO}_{4}$, filtered and concentrated to give the crude product, which was then treated with $\mathrm{HCl}_{(\mathrm{aq})}(6 \mathrm{~N}, 0.25 \mathrm{~mL})$ in $\mathrm{MeOH}(2 \mathrm{~mL})$ at room temperature. The reaction mixture was stirred at room temperature for $1 \mathrm{~h}$ and then concentrated under vacuum to give the crude product, which was purified on silica gel with $\mathrm{MeOH} / \mathrm{CH}_{2} \mathrm{Cl}_{2}$ (1:20) to afford 11 (73 $\mathrm{mg}$ ) as a yellow solid $\left(\mathrm{mp}=187-188{ }^{\circ} \mathrm{C}\right)$. Yield 5\% for three steps; ${ }^{1} \mathrm{H}-\mathrm{NMR}\left(\mathrm{DMSO}-\mathrm{d}_{6}\right) \delta 7.65(\mathrm{~d}, J=16.0 \mathrm{~Hz}, 2 \mathrm{H}), 7.49$ $(\mathrm{s}, 2 \mathrm{H}), 7.31(\mathrm{~d}, J=10.0 \mathrm{~Hz}, 2 \mathrm{H}), 7.08(\mathrm{~d}, J=8.1 \mathrm{~Hz}, 2 \mathrm{H}), 6.69(\mathrm{~d}, J=16.0 \mathrm{~Hz}, 2 \mathrm{H}), 4.85(\mathrm{t}, J=5.5 \mathrm{~Hz}$, $4 \mathrm{H}), 3.80(\mathrm{~s}, 6 \mathrm{H}), 3.74(\mathrm{~s}, 6 \mathrm{H}), 3.66-3.60(\mathrm{~m}, 8 \mathrm{H}), 1.20(\mathrm{~s}, 6 \mathrm{H}) ;{ }^{13} \mathrm{C}-\mathrm{NMR}\left(\mathrm{DMSO}-\mathrm{d}_{6}\right) \delta 193.1,173.4,167.1$, 151.6, 144.4, 141.8, 133.2, 123.8, 121,9, 118.4, 112.6, 64.0, 56.3, 51.9, 51.0, 17.3; HRMS [ESI] ${ }^{+}$calculated for $\mathrm{C}_{35} \mathrm{H}_{44} \mathrm{NaO}_{14}: 711.2629[\mathrm{M}+\mathrm{Na}]^{+}$; found: 711.2633 .

\subsection{6. (1E,6E)-1,7-bis(3,4-Dimethoxyphenyl)-4,4-bis(hydroxymethyl)hepta-1,6-diene-3,5-dione (12)}

To a stirred solution of DMC (1.270 g, $3.20 \mathrm{mmol})$ in THF (20 mL, containing $0.6 \mathrm{M}$ formaldehyde) was added DBU $(15 \mathrm{mg}, 0.10 \mathrm{mmol})$. The reaction mixture was stirred at $0{ }^{\circ} \mathrm{C}$ for $30 \mathrm{~min}$. The reaction mixture was concentrated under vacuum and then purified by flash chromatography on silica gel with $\mathrm{MeOH} / \mathrm{CH}_{2} \mathrm{Cl}_{2}$ (1:32) to afford 12 (558 mg, 42\% yield) as a yellow solid; $\mathrm{mp}=174-176{ }^{\circ} \mathrm{C} ;{ }^{1} \mathrm{H}-\mathrm{NMR}$ $\left(\mathrm{DMSO}_{-} \mathrm{d}_{6}\right) \delta 7.49(\mathrm{~d}, J=15.5 \mathrm{~Hz}, 2 \mathrm{H}), 7.48(\mathrm{~d}, J=2.0 \mathrm{~Hz}, 2 \mathrm{H}), 7.24(\mathrm{~d}, J=8.5 \mathrm{~Hz}, 2 \mathrm{H}), 6.97-6.91(\mathrm{~m}, 4 \mathrm{H})$, $4.78(\mathrm{t}, J=4.5 \mathrm{~Hz}, 2 \mathrm{H}), 4.19(\mathrm{~d}, J=4.5 \mathrm{~Hz}, 4 \mathrm{H}), 3.79(\mathrm{~s}, 12 \mathrm{H}) ;{ }^{13} \mathrm{C}-\mathrm{NMR}\left(\mathrm{DMSO}-\mathrm{d}_{6}\right) \delta 196.2,151.7,149.1$, $142.8,127.4,123.8,120,9,112.1,111.3,71.6,60.1,56.1,56.0$; HRMS [ESI] ${ }^{+}$calculated for $\mathrm{C}_{25} \mathrm{H}_{28} \mathrm{NaO}_{8}$ : $479.1682[\mathrm{M}+\mathrm{Na}]^{+}$; found: 479.1677 . 
3.1.7. 2,2-bis[(E)-3-(3,4-Dimethoxyphenyl)acryloyl]propane-1,3-diylbis[3-hydroxy-2-(hydroxymethyl)-2methylpropanoate] (14)

To a solution of $12(0.170 \mathrm{~g}, 0.37 \mathrm{mmol})$ in $\mathrm{CH}_{2} \mathrm{Cl}_{2}(4 \mathrm{~mL})$ was added $\mathrm{NEt}_{3}(0.15 \mathrm{~mL}, 1.10 \mathrm{mmol})$, $\operatorname{DMAP}(0.110 \mathrm{~g}, 0.92 \mathrm{mmol})$ and 2,2,5-trimethyl-1,3-dioxane-5-carbonyl chloride 13 (0.210 g, $1.10 \mathrm{mmol})$ sequentially at room temperature. The reaction mixture was stirred at the same temperature for $12 \mathrm{~h}$ and then concentrated under vacuum to give the crude product, which without purification was treated with $\mathrm{HCl}_{(\mathrm{aq})}(6 \mathrm{~N}, 0.1 \mathrm{~mL})$ in $\mathrm{MeOH}(0.5 \mathrm{~mL})$. The resulting mixture was stirred at room temperature for $1 \mathrm{~h}$ and then concentrated under vacuum to give the crude product, which was purified by flash chromatography on silica gel with $\mathrm{MeOH} / \mathrm{CH}_{2} \mathrm{Cl}_{2}$ (1:19) to afford compound 14 (16 mg, 7\% for two steps) as a yellow solid; $\mathrm{mp}>300{ }^{\circ} \mathrm{C} ;{ }^{1} \mathrm{H}-\mathrm{NMR}\left(\mathrm{DMSO}_{6} \mathrm{~d}_{6}\right) \delta 7.64(\mathrm{~d}, J=15.5 \mathrm{~Hz}, 2 \mathrm{H}), 7.34-7.30(\mathrm{~m}$, $4 \mathrm{H}), 7.03(\mathrm{~d}, J=15.0 \mathrm{~Hz}, 2 \mathrm{H}), 6.99(\mathrm{~d}, J=8.0 \mathrm{~Hz}, 2 \mathrm{H}), 4.74(\mathrm{~s}, 4 \mathrm{H}), 4.63(\mathrm{t}, J=5.5 \mathrm{~Hz}, 4 \mathrm{H}), 3.79(\mathrm{~s}, 12 \mathrm{H})$, 3.40-3.37 (m, 8H), 0.95(s, 6H); ${ }^{13}$ C-NMR (DMSO-d 6 ) $\delta 193.3,174.6,152.1,149.4,145.0,127.1,124.7,119,5$, 112.0, 111.4, 66.9, 63.9, 62.3, 56.1, 56.1, 50.7, 17.0; HRMS [ESI] ${ }^{+}$calculated for $\mathrm{C}_{35} \mathrm{H}_{44} \mathrm{NaO}_{14}: 711.2629$ $[\mathrm{M}+\mathrm{Na}]^{+}$; found: 711.2620 .

\subsubsection{General Procedure for the Synthesis of Compounds $2 \mathrm{~m}-6 \mathrm{~m}$}

The general procedure is illustrated immediately below with compound $\mathbf{2 m}$ as a specific example.

(1E,6E)-1,7-bis(4-Hydroxy-3-methoxyphenyl)-4,4-dimethylhepta-1,6-diene-3,5-dione (2m)

To a stirred solution of compound $2(0.450 \mathrm{~g}, 0.72 \mathrm{mmol})$ in $\mathrm{CH}_{3} \mathrm{OH}(6 \mathrm{~mL})$ were added $\mathrm{NaOMe}$ $(0.116 \mathrm{~g}, 2.16 \mathrm{mmol})$ at room temperature. The reaction mixture was stirred at the same temperature for $2 \mathrm{~h}$ and then $\mathrm{H}_{2} \mathrm{O}(5 \mathrm{~mL})$ and diluted $\mathrm{HCl}_{(\mathrm{aq})}(1 \mathrm{~N}, 1 \mathrm{~mL})$ were added to quench the reaction. The aqueous layer was separated and extracted with $\mathrm{CH}_{2} \mathrm{Cl}_{2}(3 \times 6 \mathrm{~mL})$. The combined organic extracts were washed with brine, dried over $\mathrm{MgSO}_{4}$, filtered and concentrated to give the crude product, which was then purified by flash chromatography on silica gel with EtOAc/n-hexane $/ \mathrm{CH}_{2} \mathrm{Cl}_{2}$ (1:2:1) to afford $2 \mathrm{~m}(0.245 \mathrm{~g}, 86 \%$ yield $)$ as an orange solid; $\mathrm{mp}=104-106{ }^{\circ} \mathrm{C} ;{ }^{1} \mathrm{H}-\mathrm{NMR}\left(\mathrm{CDCl}_{3}\right) \delta 7.69(\mathrm{~d}, J=15.5 \mathrm{~Hz}$, 2H), $7.12(\mathrm{dd}, J=8.0,1.5 \mathrm{~Hz}, 2 \mathrm{H}), 7.01(\mathrm{~s}, 2 \mathrm{H}), 6.91(\mathrm{~d}, J=8.5 \mathrm{~Hz}, 2 \mathrm{H}), 6.65(\mathrm{~d}, J=15.5 \mathrm{~Hz}, 2 \mathrm{H}), 5.97$ (s, 2H), $3.94(\mathrm{~s}, 6 \mathrm{H}), 1.48(\mathrm{~s}, 6 \mathrm{H}) ;{ }^{13} \mathrm{C}-\mathrm{NMR}\left(\mathrm{CDCl}_{3}\right) \delta$ 198.2, 148.6, 146.8, 144.5, 126.8, 124.1, 119.1, 114.8, 109.8, 60.8, 56.0, 14.1; HRMS [ESI] ${ }^{+}$calculated for $\mathrm{C}_{23} \mathrm{H}_{24} \mathrm{NaO}_{6}: 419.1471$ [M + Na] ${ }^{+}$; found: 419.1480

(1E,6E)-4,4-Diethyl-1,7-bis(4-hydroxy-3-methoxyphenyl)hepta-1,6-diene-3,5-dione (3m)

Yield: $87 \% ; \mathrm{mp}=114-115{ }^{\circ} \mathrm{C} ;{ }^{1} \mathrm{H}-\mathrm{NMR}\left(\mathrm{CDCl}_{3}\right) \delta 7.64(\mathrm{~d}, J=15.5 \mathrm{~Hz}, 2 \mathrm{H}), 7.05(\mathrm{dd}, J=8.3,1.5$ $\mathrm{Hz}, 2 \mathrm{H}), 6.95(\mathrm{~d}, J=2.0 \mathrm{~Hz}, 2 \mathrm{H}), 6.85(\mathrm{~d}, J=8.0 \mathrm{~Hz}, 2 \mathrm{H}), 6.59(\mathrm{~d}, J=15.5 \mathrm{~Hz}, 2 \mathrm{H}), 5.88(\mathrm{~s}, 2 \mathrm{H}), 3.88$ $(\mathrm{s}, 6 \mathrm{H}), 2.06(\mathrm{q}, J=7.5 \mathrm{~Hz}, 4 \mathrm{H}), 0.71(\mathrm{t}, J=7.5 \mathrm{~Hz}, 6 \mathrm{H}) ;{ }^{13} \mathrm{C}-\mathrm{NMR}\left(\mathrm{CDCl}_{3}\right) \delta 197.9,148.5,146.7,144.0$, $126.8,124.2,119.6,114.7,109.7,69.0,56.1,21.6,7.7$; HRMS [ESI] ${ }^{+}$calculated for $\mathrm{C}_{25} \mathrm{H}_{28} \mathrm{NaO}_{6}: 447.1784$ $[\mathrm{M}+\mathrm{Na}]^{+} ;$found: 447.1788 .

(1E,6E)-4,4-Dibenzyl-1,7-bis(4-hydroxy-3-methoxyphenyl)hepta-1,6-diene-3,5-dione (4m)

Yield: $82 \%$; mp $=134-135{ }^{\circ} \mathrm{C} ;{ }^{1} \mathrm{H}-\mathrm{NMR}\left(\mathrm{CDCl}_{3}\right) \delta 7.72(\mathrm{~d}, J=15.0 \mathrm{~Hz}, 2 \mathrm{H}), 7.26-7.21(\mathrm{~m}, 6 \mathrm{H})$, 7.15-7.13 (m, 4H), 7.07-7.05 (m, 2H), 6.90-6.89 (m, 4H), $6.58(\mathrm{dd}, J=15.5,1.0 \mathrm{~Hz}, 2 \mathrm{H}), 5.31(\mathrm{~s}, 2 \mathrm{H})$, 3.89 (s, 6H), $3.42(\mathrm{~s}, 4 \mathrm{H}) ;{ }^{13} \mathrm{C}-\mathrm{NMR}\left(\mathrm{CDCl}_{3}\right) \delta 196.9,148.7,146.8,144.0,136.6,130.4,128.1,126.8,126.6$, 124.3, 120.8, 114.8, 109.8, 70.1, 56.1, 37.7; HRMS [ESI] ${ }^{+}$calculated for $\mathrm{C}_{25} \mathrm{H}_{32} \mathrm{NaO}_{6}: 571.2097[\mathrm{M}+\mathrm{Na}]^{+}$; found: 571.2090 .

(1E,6E)-1,7-bis(4-Hydroxy-3-methoxyphenyl)-4,4-di(prop-2-yn-1-yl)hepta-1,6-diene-3,5-dione (5m)

Yield: 83\%; mp $=201-203{ }^{\circ} \mathrm{C} ;{ }^{1} \mathrm{H}-\mathrm{NMR}\left(\mathrm{CDCl}_{3}\right) \delta 7.75(\mathrm{~d}, J=15.0 \mathrm{~Hz}, 2 \mathrm{H}), 7.13(\mathrm{dd}, J=8.0,1.5$ $\mathrm{Hz}, 2 \mathrm{H}), 7.03(\mathrm{~d}, J=2.0 \mathrm{~Hz}, 2 \mathrm{H}), 6.92(\mathrm{~d}, J=8.0 \mathrm{~Hz}, 2 \mathrm{H}), 6.67(\mathrm{~d}, J=15.0 \mathrm{~Hz}, 2 \mathrm{H}), 5.97(\mathrm{~s}, 2 \mathrm{H}), 3.95$ (s, 6H), 3.19 (s, 4H), $2.04(\mathrm{~s}, 4 \mathrm{H}) ;{ }^{13} \mathrm{C}-\mathrm{NMR}\left(\mathrm{CDCl}_{3}\right) \delta 193.5,148.9,145.9,126.5,124.7,117.8,114.8,109.8$, 79.1, 71.9, 66.9, 56.1, 21.2; HRMS [ESI] ${ }^{+}$calculated for $\mathrm{C}_{27} \mathrm{H}_{28} \mathrm{O}_{6}: 471.1784$ [M + Na] ${ }^{+}$; found: 471.1783 . 
(1E,6E)-4,4-Diallyl-1,7-bis(4-hydroxy-3-methoxyphenyl)hepta-1,6-diene-3,5-dione (6m)

Yield: $85 \% ; \mathrm{mp}=160-162{ }^{\circ} \mathrm{C} ;{ }^{1} \mathrm{H}-\mathrm{NMR}\left(\mathrm{CDCl}_{3}\right) \delta 7.65(\mathrm{~d}, J=15.5 \mathrm{~Hz}, 2 \mathrm{H}), 7.06(\mathrm{dd}, J=8.3,1.5$ $\mathrm{Hz}, 2 \mathrm{H}), 6.95(\mathrm{~d}, J=2.0 \mathrm{~Hz}, 2 \mathrm{H}), 6.85(\mathrm{~d}, J=8.0 \mathrm{~Hz}, 2 \mathrm{H}), 6.61(\mathrm{~d}, J=15.5 \mathrm{~Hz}, 2 \mathrm{H}), 5.87(\mathrm{~s}, 2 \mathrm{H}), 5.54-5.49$ $(\mathrm{m}, 2 \mathrm{H}), 5.07-5.04(\mathrm{~m} 4 \mathrm{H}), 3.88(\mathrm{~s}, 6 \mathrm{H}), 2.78(\mathrm{~d}, J=7.5 \mathrm{~Hz}, 4 \mathrm{H}) ;{ }^{13} \mathrm{C}-\mathrm{NMR}\left(\mathrm{CDCl}_{3}\right) \delta$ 194.6, 148.7, 146.8, 144.6, 132.3, 126.7, 119.3, 119.1, 114.7, 109.7, 67.8, 56.1, 34.4; HRMS [ESI] ${ }^{+}$calculated for $\mathrm{C}_{27} \mathrm{H}_{24} \mathrm{NaO}_{6}$ : 467.1471 [M + Na $]^{+}$; found: 467.1477 .

\subsubsection{General Procedure for the Synthesis of Compounds 15 and 16}

The general procedure is illustrated below with compound $\mathbf{1 5}$ as a specific example. To a solution of curcumin bisacetate $17(0.76 \mathrm{~g}, 1.68 \mathrm{mmol})$ in DMF $(8 \mathrm{~mL})$ was added $\mathrm{K}_{2} \mathrm{CO}_{3}(0.58 \mathrm{~g}, 4.20 \mathrm{mmol})$ and propyl bromide $(0.435 \mathrm{~g}, 3.53 \mathrm{mmol})$ sequentially at $0{ }^{\circ} \mathrm{C}$. The reaction mixture was stirred at room temeperatre for $20 \mathrm{~h}$ and then $\mathrm{H}_{2} \mathrm{O}(10 \mathrm{~mL})$ and diluted $\mathrm{HCl}_{(\mathrm{aq})}(1 \mathrm{~N}, 5 \mathrm{~mL})$ were added to quench the reaction. The aqueous layer was separated and extracted with EtOAc $(3 \times 10 \mathrm{~mL})$. The combined organic layer was dried over $\mathrm{MgSO}_{4}$, filtered and concentrated to give the crude product, which was subjected without any purification to the base-promoted hydrolysis reaction [NaOMe $(0.190 \mathrm{~g}$, $3.53 \mathrm{mmol}), \mathrm{MeOH}(5 \mathrm{~mL})]$. The reaction was followed by TLC until no starting material was present. The resulting mixture was then concentrated to give the crude product, which was then purified by flash chromatography on silica gel with EtOAc/n-hexane/ $\mathrm{CH}_{2} \mathrm{Cl}_{2}$ (1:2:1) to afford compound 15 (0.213 g, $28 \%$ yield for two steps) as a yellow solid.

\section{(1E,6E)-1,7-bis(4-Hydroxy-3-methoxyphenyl)-4,4-dipropylhepta-1,6-diene-3,5-dione (15)}

$\mathrm{mp}=137-139{ }^{\circ} \mathrm{C} ;{ }^{1} \mathrm{H}-\mathrm{NMR}\left(\mathrm{CDCl}_{3}\right) \delta 7.69(\mathrm{~d}, J=15.0 \mathrm{~Hz}, 2 \mathrm{H}), 7.11(\mathrm{dd}, J=8.3,1.5 \mathrm{~Hz}, 2 \mathrm{H}), 7.01$ $(\mathrm{d}, J=1.5 \mathrm{~Hz}, 2 \mathrm{H}), 6.91(\mathrm{~d}, J=8.0 \mathrm{~Hz}, 2 \mathrm{H}), 6.65(\mathrm{~d}, J=15.5 \mathrm{~Hz}, 2 \mathrm{H}), 5.90(\mathrm{~s}, 2 \mathrm{H}), 3.94(\mathrm{~s}, 6 \mathrm{H}), 2.05-2.01$ $(\mathrm{m}, 4 \mathrm{H}), 1.15-1.08(\mathrm{~m}, 4 \mathrm{H}), 0.95(\mathrm{t}, J=7.5 \mathrm{~Hz}, 6 \mathrm{H}) ;{ }^{13} \mathrm{C}-\mathrm{NMR}\left(\mathrm{CDCl}_{3}\right) \delta 197.9,148.5,146.7,144.0,126.8$, 124.1, 119.5, 114.7, 109.7, 68.4, 56.1, 31.8, 16.8, 14.7; HRMS [ESI] ${ }^{+}$calculated for $\mathrm{C}_{27} \mathrm{H}_{32} \mathrm{NaO}_{6}: 475.2097$ $[\mathrm{M}+\mathrm{Na}]^{+}$; found: 475.2100 .

\section{(1E,6E)-4,4-Dibutyl-1,7-bis(4-hydroxy-3-methoxyphenyl)hepta-1,6-diene-3,5-dione (16)}

$\mathrm{mp}=144-146{ }^{\circ} \mathrm{C} ;{ }^{1} \mathrm{H}-\mathrm{NMR}\left(\mathrm{CDCl}_{3}\right) \delta 7.68(\mathrm{~d}, J=15.5 \mathrm{~Hz}, 2 \mathrm{H}), 7.11(\mathrm{dd}, J=8.3,1.5 \mathrm{~Hz}, 2 \mathrm{H})$, $7.01(\mathrm{~s}, 2 \mathrm{H}), 6.91(\mathrm{~d}, J=8.2 \mathrm{~Hz}, 2 \mathrm{H}), 6.65(\mathrm{~d}, J=15.5 \mathrm{~Hz}, 2 \mathrm{H}), 6.01(\mathrm{~s}, 2 \mathrm{H}), 3.93(\mathrm{~s}, 6 \mathrm{H}), 2.07-2.03(\mathrm{~m}$, $4 \mathrm{H}), 1.37-1.33(\mathrm{~m}, 4 \mathrm{H}), 1.10-1.03(\mathrm{~m}, 4 \mathrm{H}), 0.90(\mathrm{t}, J=7.3 \mathrm{~Hz}, 6 \mathrm{H}) ;{ }^{13} \mathrm{C}-\mathrm{NMR}\left(\mathrm{CDCl}_{3}\right) \delta$ 198.0, 148.5, 146.8, 144.0, 126.9, 124.1, 119.5, 114.7, 109.7, 68.3, 56.1, 29.1, 25.5, 23.2, 13.9; HRMS [ESI] ${ }^{+}$calculated for $\mathrm{C}_{29} \mathrm{H}_{36} \mathrm{NaO}_{6}: 503.2410[\mathrm{M}+\mathrm{Na}]^{+}$; found: 503.2400 .

\subsubsection{0. (E)-1,7-bis(4-Hydroxy-3-methoxyphenyl)-4,4-dimethylhept-1-ene-3,5-dione (18)}

To a stirred solution of compound $2 \mathrm{~m}(0.740 \mathrm{~g}, 1.87 \mathrm{mmol})$ in EtOAc $(10 \mathrm{~mL})$ was added Pd/C $(37 \mathrm{mg}, 5 \% \mathrm{w} / \mathrm{w})$ in one portion. The resulting mixture was hydrogenated under 1 atmosphere of $\mathrm{H}_{2}$ at room temperature. After $1 \mathrm{~h}$, the mixture was filtered by celite and concentrated to give the crude product, which was purified by flash chromatography on silica gel with EtOAc/n-hexane/ $\mathrm{CH}_{2} \mathrm{Cl}_{2}(1: 2: 1)$ to afford compound 18 (140 mg, 19\% yield) as a light-yellow oil and recover compound $2 \mathrm{~m}(500 \mathrm{mg}$, $67 \%$ yield). ${ }^{1} \mathrm{H}-\mathrm{NMR}\left(\mathrm{CDCl}_{3}\right) \delta 7.61(\mathrm{~d}, J=15.5 \mathrm{~Hz}, 1 \mathrm{H}), 7.07(\mathrm{dd}, J=8.5,1.5 \mathrm{~Hz}, 1 \mathrm{H}), 6.95-6.93(\mathrm{~m}, 2 \mathrm{H})$, $6.75(\mathrm{~d}, J=8.0 \mathrm{~Hz}, 1 \mathrm{H}), 6.65-6.62(\mathrm{~m}, 2 \mathrm{H}), 6.49(\mathrm{~d}, J=15.5 \mathrm{~Hz}, 1 \mathrm{H}), 6.07(\mathrm{~s}, 1 \mathrm{H}), 5.45(\mathrm{~s}, 1 \mathrm{H}), 3.94(\mathrm{~s}, 3 \mathrm{H})$, $3.79(\mathrm{~s}, 3 \mathrm{H}), 2.83(\mathrm{t}, J=7.5 \mathrm{~Hz}, 2 \mathrm{H}), 2.74(\mathrm{t}, J=7.0 \mathrm{~Hz}, 2 \mathrm{H}), 1.38(\mathrm{~s}, 6 \mathrm{H}) ;{ }^{13} \mathrm{C}-\mathrm{NMR}\left(\mathrm{CDCl}_{3}\right) \delta 209.4,197.7$, 148.7, 146.8, 146.3, 144.7, 143.8, 132.6, 126.9, 123.9, 121.0, 118.2, 114.9, 114.2, 111.0, 110.0, 61.7, 56.0, 55.7, 40.7, 29.6, 21.0; HRMS [ESI] ${ }^{+}$calculated for $\mathrm{C}_{23} \mathrm{H}_{26} \mathrm{NaO}_{6}: 421.1627[\mathrm{M}+\mathrm{Na}]^{+}$; found: 421.1233 . 
3.1.11. 1,7-bis(4-Hydroxy-3-methoxyphenyl)-4,4-dimethylheptane-3,5-dione (19) and 5-hydroxy-1,7-bis(4hydroxy-3-methoxyphenyl)-4,4-dimethylheptan-3-one (20)

To a stirred solution of compound $2 \mathrm{~m}(0.885 \mathrm{~g}, 2.23 \mathrm{mmol})$ in $\mathrm{MeOH}(10 \mathrm{~mL})$ was added $\mathrm{Pd} / \mathrm{C}$ $(45 \mathrm{mg}, 10 \% \mathrm{w} / \mathrm{w})$ in one portion. The resulting mixture was hydrogenated under 1 atmosphere of $\mathrm{H}_{2}$ at room temperature. After $2 \mathrm{~h}$, the mixture was filtered by celite and concentrated to give the crude product, which was purified by flash chromatography on silica gel with EtOAc/n-hexane/ (1:2) to afford compound 19 (465 mg, 52\% yield) as a colorless oil and compound 20 (206 mg, 23\% yield) as a colorless oil.

Compound 19: ${ }^{1} \mathrm{H}-\mathrm{NMR}\left(\mathrm{CDCl}_{3}\right) \delta 6.83(\mathrm{~d}, J=8.0 \mathrm{~Hz}, 2 \mathrm{H}), 6.65(\mathrm{~d}, J=2.0 \mathrm{~Hz}, 2 \mathrm{H}), 6.63-6.61(\mathrm{~m}$, 2H), $5.51(\mathrm{~s}, 2 \mathrm{H}), 3.87(\mathrm{~s}, 6 \mathrm{H}), 2.76(\mathrm{t}, J=7.0 \mathrm{~Hz}, 4 \mathrm{H}), 2.58(\mathrm{t}, J=7.0 \mathrm{~Hz}, 4 \mathrm{H}), 1.29(\mathrm{~s}, 6 \mathrm{H}) ;{ }^{13} \mathrm{C}-\mathrm{NMR}$ $\left(\mathrm{CDCl}_{3}\right) \delta$ 208.9, 146.4, 143.9, 132.7, 120.9, 114.3, 114.9, 111.7, 62.4, 55.9, 40.5, 29.4, 21.0; HRMS [ESI] ${ }^{+}$ calculated for $\mathrm{C}_{23} \mathrm{H}_{28} \mathrm{NaO}_{6}: 423.1784[\mathrm{M}+\mathrm{Na}]^{+}$; found: 423.1780 .

Compound 20: ${ }^{1} \mathrm{H}-\mathrm{NMR}\left(\mathrm{CDCl}_{3}\right) \delta 6.86-6.83(\mathrm{~m}, 2 \mathrm{H}), 6.72-6.66(\mathrm{~m}, 4 \mathrm{H}), 5.62-5.61(\mathrm{br} \mathrm{s}, 2 \mathrm{H})$, $3.89(\mathrm{~s}, 3 \mathrm{H}), 3.87(\mathrm{~s}, 3 \mathrm{H}), 3.71-3.69(\mathrm{~m}, 1 \mathrm{H}), 2.90-2.71(\mathrm{~m}, 5 \mathrm{H}), 2.61-2.51(\mathrm{~m}, 2 \mathrm{H}), 1.71-1.55(\mathrm{~m}, 2 \mathrm{H})$, $1.13(\mathrm{~s}, 3 \mathrm{H}), 1.08(\mathrm{~s}, 3 \mathrm{H}) ;{ }^{13} \mathrm{C}-\mathrm{NMR}\left(\mathrm{CDCl}_{3}\right) \delta 216.5,146.4,143.9,143.7,133.9,133.1,120.9,120.8,114.4$, 114.3, 111.2, 111.1, 55.9, 51.7, 40.3, 33.7, 32.6, 29.4, 21.7, 19.3; HRMS [ESI] ${ }^{+}$calculated for $\mathrm{C}_{23} \mathrm{H}_{30} \mathrm{NaO}_{6}$ : $425.4768[\mathrm{M}+\mathrm{Na}]^{+}$; found: 425.4760 .

\subsubsection{1,7-bis(4-Hydroxy-3-methoxyphenyl)-4,4-dimethylheptane-3,5-diol (21)}

To a solution of compound 20 (110 mg, $0.27 \mathrm{mmol})$ in $\mathrm{MeOH}(3 \mathrm{~mL})$ was added $\mathrm{NaBH}_{4}(30 \mathrm{mg}$, $0.81 \mathrm{mmol})$ at $0{ }^{\circ} \mathrm{C}$. The resulting mixture was allowed to stir at room temperature for $2 \mathrm{~h}$, and then $\mathrm{H}_{2} \mathrm{O}(3 \mathrm{~mL})$ was added. The aqueous layer was separated and extracted with $\mathrm{CH}_{2} \mathrm{Cl}_{2}(3 \times 6 \mathrm{~mL})$. The combined organic extracts were washed brine, dried over $\mathrm{MgSO}_{4}$, filtered and concentrated to give the crude residue, which was purified by flash chromatography on silica gel with EtOAc/n-hexane/ (1:1) to afford compound 21 (34 mg, 31\% yield) as a colorless oil. ${ }^{1} \mathrm{H}-\mathrm{NMR}\left(\mathrm{CDCl}_{3}\right) \delta 6.86(\mathrm{~d}, J=8.0$ $\mathrm{Hz}, 2 \mathrm{H}), 6.74-6.71(\mathrm{~m}, 4 \mathrm{H}), 5.63(\mathrm{~s}, 2 \mathrm{H}), 3.89$ (s, 6H), 3.59-3.56 (m, 2H), $3.11(\mathrm{~s}, 2 \mathrm{H}), 2.85-2.71(\mathrm{~m}, 2 \mathrm{H})$, 2.61-2.55 (m, 2H), 1.81-1.72 (m, 4H), $0.90(\mathrm{~s}, 6 \mathrm{H}) ;{ }^{13} \mathrm{C}-\mathrm{NMR}\left(\mathrm{CDCl}_{3}\right) \delta$ 146.5, 143.7, 134.1, 134.0, 120.9, 114.3, 111.1, 78.7, 55.9, 40.3, 33.9, 32.8, 21.0; HRMS [ESI] ${ }^{+}$calculated for $\mathrm{C}_{23} \mathrm{H}_{32} \mathrm{NaO}_{6}: 427.4928[\mathrm{M}+$ $\mathrm{Na}]^{+}$; found: 427.4933 .

\subsection{Biological Assays}

\subsubsection{In Vitro MTT [3-(4,5-Dimethylthiazaol-2-yl)-2,4-diphenyltetrazolium bromide] Assay}

Cell viability was evaluated by measuring the reduction in MTT to yield blue formazan. Cells were cultured in 96-well plates, allowed to attach overnight, and then treated with compounds. After treatment, MTT solution $(1 \mathrm{mg} / \mathrm{mL})$ was added to each well, and plates were incubated for another $2 \mathrm{~h}$. Medium was removed, blue formazan was dissolved in DMSO, and the absorbance was read at $570 \mathrm{~nm}$ by Multiskan Go spectrophotometer (Thermo Scientific, Madison, WI, USA).

\subsubsection{In Vivo Antitumor Activity Assay}

Male nu/nu mice (5 weeks old) from National Laboratory Animal Center (Taipei, Taiwan) were maintained under the procedures and guidelines provided by the Institutional Animal Care and Use Committee of the National Health Research Institutes (Taipei, Taiwan). All experiments were supervised under the Institutional Animal Care and Use Committee, China Medical University, Taichung, Taiwan with a protocol number (CMUIACUC-2018-278). HCT-116 colon cancer cells $\left(5 \times 10^{6}\right.$ cells per mouse) were suspended in $0.1 \mathrm{~mL}$ of Matrigel solution (50\% v/v Matrigel in PBS) and inoculated into the mammary fat pads of the mice. When the tumor size reached $100 \mathrm{~mm}^{3}$, the tumor-bearing mice were randomly divided into four groups for treating with vehicle ( $5 \%$ ethanol and $10 \%$ tween 80 in $85 \%$ saline, $0.1 \mathrm{~mL}$ ) and 2 (p.o. 50, 100 and $150 \mathrm{mg} / \mathrm{kg} /$ day body weight) respectively. Compounds was administered via oral route daily for 30 days. 5-Fluorouracil-treated group (i.p. $30 \mathrm{mg} / \mathrm{kg}$ ) is the 
positive control. Tumor size and mouse body weight were measured once every 3 days, and tumor volume $\left(\mathrm{mm}^{3}\right)$ was calculated using the equation: length $\times(\text { width })^{2} \times 0.5$. At the end of experiments, mice were sacrificed.

\subsubsection{The Preliminary Pharmacokinetic Evaluation of 2 in Rat}

Drug administration and blood collection

Male Sparague-Dawley rat (420 g) from National Laboratory Animal Center, Taipei, Taiwan were maintained under the regulations of the Institutional Animal Care and Use Committee of the National Health Research Institutes, Taiwan. The animal studies were supervised under the Institutional Animal Care and Use Committee, China Medical University, Taichung, Taiwan with a protocol number (CMUIACUC-2018-278). Rat was fasted for $16 \mathrm{~h}$ before dosing. Compound 2 was dissolved in aqueous solution ( $5 \%$ ethanol and $10 \%$ Tween 80 in $85 \%$ saline) and administrated via oral gavage at a dosage of $100 \mathrm{mg} / \mathrm{kg}$. Blood samples were collected at selected time points $(5,10,20,30,60,120,240,360,480 \mathrm{~min})$ post dose and centrifuged at $10,000 \times g$ for $15 \mathrm{~min}$ to provide serum samples, which were stored at $-80^{\circ} \mathrm{C}$ until subsequent sample extraction.

\subsubsection{Analysis of $2,2 \mathrm{~m}, 18,19,20,21,22$ and 23 in Serum}

Methods for the preparation of $\mathbf{2}, \mathbf{2 m}, \mathbf{1 8}, \mathbf{1 9}, \mathbf{2 0}$ and $\mathbf{2 1}$ serum sample are delineated as follows. $50 \mu \mathrm{L}$ of acetate buffer (pH 5.0), $50 \mu \mathrm{L}$ of ascorbic acid $(200 \mathrm{mg} / \mathrm{mL})$, and $50 \mu \mathrm{L}$ of $0.1 \mathrm{~N} \mathrm{HCl}$ solution was added into $100 \mu \mathrm{L}$ of serum which was collected at different time points). The resulting mixture was partitioned with $250 \mu \mathrm{L}$ of ethyl acetate (containing $5.0 \mu \mathrm{g} / \mathrm{mL}$ of butyl paraben as the internal standard). After centrifuging at $10,000 \times g$ for $15 \mathrm{~min}$, the upper organic layer was separated and dried under nitrogen gas to provide the crude sample, which was diluted with an appropriate volume of acetonitrile for LC-MS analysis.

The amount of $\mathbf{2 2}$ and $\mathbf{2 3}$ were analyzed by the serum samples before and after treatment with enzyme solution. The procedure for enzyme treatment is shown as follows. $100 \mu \mathrm{L}$ of serum was treated with enzyme solution $(50 \mu \mathrm{L}$; containing 1000 units $/ \mathrm{mL}$ of sulfatase and $39861 \mathrm{units} / \mathrm{mL}$ of $\beta$-glucuronidase in $\mathrm{pH} 5.0$ acetate buffer), $50 \mu \mathrm{L}$ of $0.1 \mathrm{~N} \mathrm{HCl}$ solution and $50 \mu \mathrm{L}$ of ascorbic acid $(200 \mathrm{mg} / \mathrm{mL})$ in the light protected tubes at $37^{\circ} \mathrm{C}$. For optimal hydrolysis efficiency, the incubation time was decided as $2 \mathrm{~h}$ based on a previous study [35]. The mixture was then partitioned with $250 \mu \mathrm{L}$ of ethyl acetate (containing $5.0 \mu \mathrm{g} / \mathrm{mL}$ of butyl paraben as the internal standard). After centrifuging at $10,000 \times g$ for $15 \mathrm{~min}$, the upper organic layer was separated and dried under nitrogen gas to provide the crude sample, which was diluted with an appropriate volume of acetonitrile for LC analysis.

\subsubsection{LC-MS Analysis Method}

All samples obtained from in vivo pharmacokinetic studies were assayed using LC-MS for the analysis of $\mathbf{2}$ and the corresponding metabolites. The Waters ACQUITY UPLC I-Class system (Waters Corp., Milford, MA, USA) was utilized. System control and all of the mass spectrometry data were acquired and analyzed using UNIFI software (Waters Corp.). For sample separation, the LC was equipped with an Inertsil ph-3 $(50 \times 2.1 \mathrm{~mm}, 2 \mu \mathrm{m}$ particle size) RPLC column (GL Sciences Inc. Tokyo, Japan) in which the column temperature was held at $35^{\circ} \mathrm{C}$, injection volume was $7.5 \mu \mathrm{L}$, and the flow rate of the mobile phase was $200 \mu \mathrm{L} / \mathrm{min}$. The elution started from $50 \%$ mobile phase A (ultrapure water $+0.1 \%$ formic acid) and $50 \%$ mobile phase B (100\% methanol $+0.1 \%$ formic acid), held at $50 \% \mathrm{~B}$ for $0.5 \mathrm{~min}$, raised to $95 \% \mathrm{~B}$ in $5.5 \mathrm{~min}$, held at $95 \%$ B for $1 \mathrm{~min}$, and then lowered to $50 \% \mathrm{~B}$ in $1 \mathrm{~min}$. Before sample injection, the column was equilibrated by pumping $50 \% \mathrm{~B}$ for $4 \mathrm{~min}$. The analysis of target compounds for all samples was performed by using a Waters Vion IMS QTof mass spectrometer. Data were acquired in the electrospray ionization (ESI) positive ion $\mathrm{MS}^{\mathrm{E}}$ mode with range of $\mathrm{m} / \mathrm{z}$ $100-1000$ and $0.5 \mathrm{~s}$ scan time. Parameters were set as capillary voltage of $2.5 \mathrm{kV}$, source temperature of $100{ }^{\circ} \mathrm{C}$, desolvation temperature at $250^{\circ} \mathrm{C}$, cone gas maintained at $10 \mathrm{~L} / \mathrm{h}$, desolvation gas maintained 
at $600 \mathrm{~L} / \mathrm{h}$. The acquired $\mathrm{m} / \mathrm{z}$ and isotope pattern were processed by UNIFI software to illustrate chromatogram, and the amounts of compound was calculated with the integrated peak area of signals.

\section{Conclusions}

Here, structural modifications at the C-4 position of compound 1, a 2,2-bis(hydroxymethyl)propionate curcumin prodrug, with polar and nonpolar functional groups were performed to form a series of 4,4-disubstituted analogs of 1 and DMC. The in vitro anti-proliferative assay of these derivatives elucidated an obvious SAR in which the enhancement of polarity on C-4 resulted in the erosion of anticancer activity. The ester prodrug characteristics of 2-6 motivated us to synthesize their hydrolysis compounds $2 \mathrm{~m}-6 \mathrm{~m}, \mathbf{1 5}$, and $\mathbf{1 6}$, whose anticancer activities were highly dependent on the volume and length of the C-4 alkyl chains. The preliminary pharmacokinetic evaluations indicated that the esterase-mediated hydrolysis of $\mathbf{2}$ proceeded smoothly to produce $\mathbf{2 m}$, which in turn was reduced to 18 and 19 as major phase I metabolites. The phase II metabolic pathway was confirmed by the detection of glucuronide 22 and sulfate $\mathbf{2 3}$. However, it is still possible that reduction precedes ester hydrolysis to provide the hydrogenated counterparts of $\mathbf{2}$, which possess novel chemical skeletons with unknown biological activity.

Our preliminary pharmacokinetic results also shed light on future directions for the structural modification of the original compounds. Additional modifications have been scheduled to reduce the high propensity towards ester hydrolysis by converting the methyl of 2,2-bis(hydroxymethyl)propionate group into more bulky alkyl groups. Pharmacokinetic studies have been designed to identify, biologically evaluate, and quantify the possible metabolites. Apart from this, compound 2 and $\mathbf{2 m}$ may behave like $\mathbf{1}$ which acts on multiple targets and signaling pathways. The differences between the mechanism of action of $\mathbf{2}, \mathbf{2} \mathrm{m}$ and $\mathbf{1}$ are not definitively understood. Currently, we are actively investigating the mechanism of action and pharmacokinetic parameters of $\mathbf{2}$ and $\mathbf{2 m}$, including $\mathrm{T}_{1 / 2}$, AUC, and $\mathrm{C}_{\max }$, and the results will be reported in due course. The animal study showed that compound 2 inhibits tumor growth by $45 \%$ at a dose of $100 \mathrm{mg} / \mathrm{kg}$ in HCT-116 xenograft nude mice. Thus, twice-a-day (BID) dosing formulations for achieving higher therapeutic efficacy at lower doses should be considered in further development of title curcuminoid derivatives as anticancer drug candidates.

Supplementary Materials: The following are available online. Scheme S1: PLE mediated hydrolysis of curcumin 2,2-bis(hydroxymethyl)propionate 1. Figure S1: The HPLC analysis of compound 18, 19, 20, 21, 22 and 23. Copies of ${ }^{1} \mathrm{H}$ and ${ }^{13} \mathrm{C}$ NMR spectra of the new products.

Author Contributions: D.-Y.L. performed the preliminary pharmacokinetic analysis and wrote experimental section and supplementary material file. Y.-C.H. designed the preliminary pharmacokinetic study and integrated the experimental data. J.-S.Y. and H.-Y.L. performed the in vivo assay and in vivo animal study. K.-H.L. and T.-Y.C. reviewed and revised the manuscript. S.-C.K. designed the target compounds and interpreted the experimental data. M.-T.H. designed and synthesized targeted compounds. S.-C.K. and M.-T.H. are the responsible researchers, who wrote and edited the manuscript. All authors have read and agreed to the published version of the manuscript.

Funding: We are grateful to Ministry of Science and Technology, Taiwan (MOST 107-2320-B-039-028) for financial support. Partial support was also provided by the "Chinese Medicine Research Center, China Medical University" from The Featured Areas Research Center Program within the framework of the Higher Education Sprout Project by the Ministry of Education (MOE) in Taiwan (CMRC-CHM-5) awarded to S. C. Kuo.

Conflicts of Interest: The authors declare no conflict of interest.

\section{References}

1. Strimpakos, A.S.; Sharma, R.A. Curcumin: Preventive and therapeutic properties in laboratory studies and clinical trials. Antioxid. Redox Signal. 2008, 10, 511-546. [CrossRef]

2. Nabavi, S.F.; Thiagarajan, R.; Rastrelli, L.; Daglia, M.; Sobarzo-Sánchez, E.; Alinezhad, H.; Nabavi, S.M. Curcumin: A natural product for diabetes and its complications. Curr. Top Med. Chem. 2015, 15, 2445-2455. [CrossRef]

3. Mathew, D.; Hsu, W.L. Antiviral potential of curcumin. J. Funct. Foods 2018, 40, 692-699. [CrossRef] 
4. Sahebkar, A.; Henrotin, Y. Analgesic efficacy and safety of curcuminoids in clinical practice: A systematic review and meta-analysis of randomized controlled trials. Pain Med. 2016, 17, 1192-1202. [CrossRef] [PubMed]

5. Osawa, T. Nephroprotective and hepatoprotective effects of curcuminoids. Adv. Exp. Med. Biol. 2007, 595, 407-423. [PubMed]

6. Miriyala, S.; Panchatcharam, M.; Rengarajulu, P. Cardioprotective effects of curcumin. Adv. Exp. Med. Biol. 2007, 595, 359-377. [PubMed]

7. Shishodia, S. Molecular mechanisms of curcumin action: Gene expression. Biofactors 2013, 39, 37-55. [CrossRef] [PubMed]

8. Gupta, S.C.; Prasad, S.; Kim, J.H.; Patchva, S.; Webb, L.J.; Priyadarsini, I.K.; Aggarwal, B.B. Multitargeting by curcumin as revealed by molecular interaction studies. Nat. Prod. Rep. 2011, 28, 1937-1955. [CrossRef] [PubMed]

9. Bordoloi, D.; Roy, N.K.; Monisha, J.; Padmavathi, G.; Kunnumakkara, A.B. Multi-targeted agents in cancer cell chemosensitization: What we learn from curcumin thus far. Recent Pat. Anti-Canc. 2016, 11, 67-97. [CrossRef] [PubMed]

10. Kunnumakkara, A.B.; Anand, P.; Aggarwal, B.B. Curcumin inhibits proliferation, invasion, angiogenesis and metastasis of different cancers through interaction with multiple cell signaling proteins. Cancer Lett. 2008, 269, 199-225. [CrossRef]

11. Nelson, K.M.; Dahlin, J.L.; Bisson, J.; Graham, J.; Pauli, G.F.; Walters, M.A. The essential medicinal chemistry of curcumin. J. Med. Chem. 2017, 60, 1620-1637. [CrossRef] [PubMed]

12. Schieffer, G.W. Pressurized liquid extraction of curcuminoids and curcuminoid degradation products from turmeric (curcuma longa) with subsequent HPLC assays. J. Liq. Chromatogr. Relat. Technol. 2002, 25, 3033-3044. [CrossRef]

13. Schneider, C.; Gordon, O.N.; Edwards, R.L.; Luis, P.B. Degradation of curcumin: From mechanism to biological implications. J. Agric. Food Chem. 2015, 63, 7606-7614. [CrossRef] [PubMed]

14. Priyadarsini, K.I.; Maity, D.K.; Naik, G.H.; Kumar, M.S.; Unnikrishnan, M.K.; Satav, J.G.; Mohan, H. Role of phenolic $\mathrm{O}-\mathrm{H}$ and methylene hydrogen on the free radical reactions and antioxidant activity of curcumin. Free Radic. Biol. Med. 2003, 35, 475-484. [CrossRef]

15. Sharma, R.A.; Steward, W.P.; Gescher, A.J. Pharmacokinetics and pharmacodynamics of curcumin. Adv. Exp. Med. Biol. 2007, 595, 453-470. [PubMed]

16. Ireson, C.; Orr, S.; Jones, D.J.; Verschoyle, R.; Lim, C.K.; Luo, J.L.; Howells, L.; Plummer, S.; Jukes, R.; Williams, M.; et al. Characterization of metabolites of the chemopreventive agent curcumin in human and rat hepatocytes and in the rat in vivo, and evaluation of their ability to inhibit phorbol ester-induced prostaglandin E2 production. Cancer Res. 2001, 61, 1058-1064. [PubMed]

17. Rodrigues, F.C.; Anil Kumar, N.A.; Thakur, G. Developments in the anticancer activity of structurally modified curcumin: An up-to-date review. Eur. J Med. Chem. 2019, 177, 76-104. [CrossRef]

18. Tomeh, M.A.; Hadianamrei, R.; Zhao, X. A Review of Curcumin and Its Derivatives as Anticancer Agents. Int. J. Mol. Sci. 2019, 20, 1033. [CrossRef]

19. Di Martino, R.M.C.; De Simone, A.; Andrisano, V.; Bisignano, P.; Bisi, A.; Gobbi, S.; Rampa, A.; Fato, R.; Bergamini, C.; Perez, D.I.; et al. Versatility of the curcumin scaffold: Discovery of potent and balanced dual BACE-1 and GSK-3b inhibitors. J. Med. Chem. 2016, 59, 531-544. [CrossRef]

20. Noureddin, S.A.; El-Shishtawy, R.M.; Al-Footy, K.O. Curcumin analogues and their hybrid molecules as multifunctional drugs. Eur. J. Med. Chem. 2019, 82, 11631-11671.

21. Barzegar, A.; Moosavi-Movahedi, A.A. Intracellular ROS protection efficiency and free radical-scavenging activity of curcumin. PLoS ONE 2011, 6, e26012. [CrossRef] [PubMed]

22. Epstein, J.; Sanderson, I.R.; Macdonald, T.T. Curcumin as a therapeutic agent: The evidence of in vitro, animal and human studies. Br. J. Nutr. 2010, 103, 1545-1557. [CrossRef] [PubMed]

23. For the clinical progress of curcumin, refer to https://clinicaltrials.gov/.

24. Hsieh, M.T.; Chang, L.C.; Hung, H.Y.; Lin, H.Y.; Shih, M.H.; Tsai, C.H.; Kuo, S.C.; Lee, K.H. New bis(hydroxymethyl) alkanoate curcuminoid derivatives exhibit activity against triple-negative breast cancer in vitro and in vivo. Eur. J Med. Chem. 2017, 131, 141-151. [CrossRef] [PubMed]

25. Berry, L.M.; Wollenberg, L.; Zhao, Z. Esterase activities in the blood, liver and intestine of several preclinical species and humans. Drug Metab. Lett. 2009, 3, 70-77. [CrossRef] 
26. Shi, Q.; Shih, C.C.; Lee, K.H. Novel anti-prostate cancer curcumin analogues that enhance androgen receptor degradation activity. Anticancer Agents Med. Chem. 2009, 9, 904-912. [CrossRef]

27. 2,2,5-trimethyl-1,3-dioxane-5-carbonyl chloride 13 was formed by treating the acid counterpart with thionyl chloride. For detailed procedure, see: R. Giri, X. Chen, J.Q. Yu, Palladium-catalyzed asymmetric iodination of unactivated C-H bonds under mild conditions. Angew Chem. Int. Ed. Engl. 2005, 29, 2112-2115.

28. Basile, V.; Ferrari, E.; Lazzari, S.; Belluti, S.; Pignedoli, F.; Imbriano, C. Curcumin derivatives: Molecular basis of their anti-cancer activity. Biochem. Pharmacol. 2009, 78, 1305-1315. [CrossRef]

29. Prasad, S.; Tyagi, A.K.; Aggarwal, B.B. Recent developments in delivery, bioavailability, absorption and metabolism of curcumin: The golden pigment from golden spice. Cancer Res. Treat. 2014, 46, 2-18. [CrossRef]

30. Liederer, B.M.; Borchardt, R. Enzymes involved in the bioconversion of ester-based prodrugs. J. Pharm. Sci. 2006, 95, 1177-1195. [CrossRef]

31. Kunihiro, A.G.; Luis, P.B.; Brickey, J.A.; Julia, A.; Jen, B.F.; Chow, H.H.S.; Schmeider, C.; Funk, J.L. Beta-glucuronidase catalyzes deconjugation and activation of curcumin-glucuronide in bone. J. Nat. Prod. 2019, 82, 500-509. [CrossRef]

32. Ozawa, H.; Imaizumi, A.; Sumi, Y.; Hashimoto, T.; Kanai, M.; Makino, Y.; Tsuda, T.; Takahashi, N.; Kakeya, H. Curcumin $\beta$-D-glucuronide plays an important role to keep high levels of free-form curcumin in the blood. Biol. Pharm. Bull. 2017, 40, 1515-1524. [CrossRef] [PubMed]

33. Ge, S.; Tu, Y.; Hu, M. Challenges and opportunities with predicting in vivo phase II metabolism via glucuronidation from in vitro data. Curr. Pharmacol. Rep. 2016, 2, 326-338. [CrossRef] [PubMed]

34. Yang, K.Y.; Lin, L.C.; Tseng, T.Y.; Wang, S.C.; Tsai, T.H. Oral bioavailability of curcumin in rat and the herbal analysis from Curcuma longa by LC-MS/MS. J. Chromatogr. B Anal. Technol.Biomed. Life Sci. 2007, 853, 183-189. [CrossRef] [PubMed]

35. Hsieh, Y.W.; Huang, C.Y.; Yang, S.Y.; Peng, Y.H.; Yu, C.P.; Lee Chao, P.D.; Chi, H.Y. Oral intake of curcumin markedly activated CYP 3A4: In vivo and ex-vivo studies. Sci. Rep. 2014, 4, 6587-6594. [CrossRef] [PubMed]

Sample Availability: Samples of the compounds are not available from the authors.

(C) 2020 by the authors. Licensee MDPI, Basel, Switzerland. This article is an open access article distributed under the terms and conditions of the Creative Commons Attribution (CC BY) license (http://creativecommons.org/licenses/by/4.0/). 